
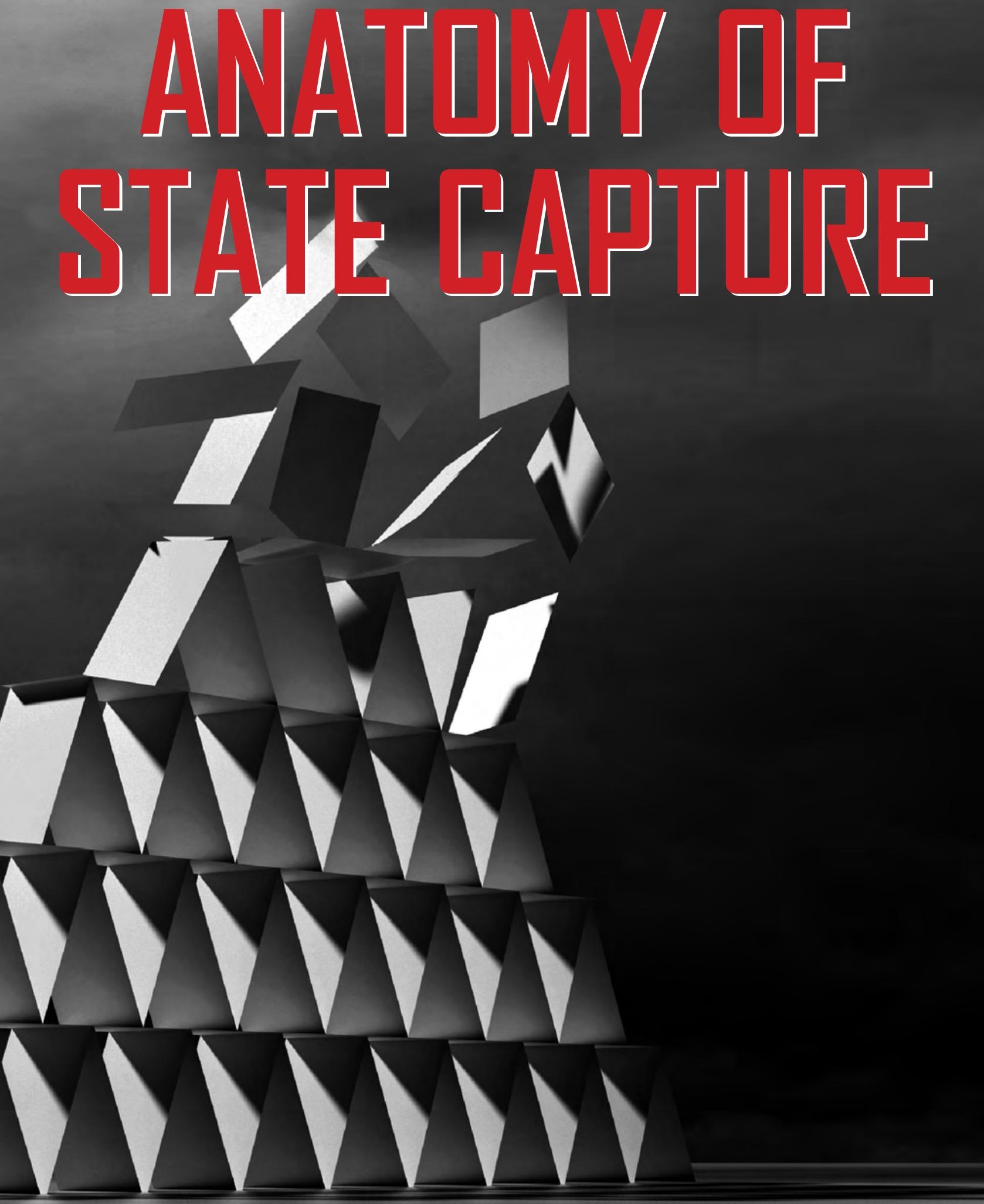

Nina Callaghan, Rabyn Foley and Mark Swilling (EDıtoRs) 


\section{TOWARDS A POLITICAL ECONOMY OF SOUTH AFRICAN RACKETS}

Mark Swilling and Sanet Madonsela

\section{$2.1 \quad$ INTRODUCTION}

As argued in the Introduction to this book, we need to understand what state capture is all about and how the actual participants in state capture engage and make deals. To answer this more granular question, it was proposed that there is a specific 'way of doing business' in South Africa that involves ways of enrolling significant numbers of people into a particular set of 'rackets'. A racket, it was argued, "can be defined as a pattern of behaviour that enables the racketeer to enrol others into acting out a fundamental untruth that is often masked by a seemingly credible story". Ultimately, rackets are about the abuse of power to secure consent. The rackets that were discussed were as follows:

- Conspiracy: here two or more relatively autonomous parties mutually agree to cooperate in secret to achieve a shared goal.

- Collusion: this refers to the way a relatively more powerful racketeer uses various 'coercive feelings' to ensure that one or more 'junior' parties agree to actively collude in ways that are often denied by the story that the racketeer tells, and the enrolled person chooses to believe.

- Coercion: this refers to the way a racketeer uses various direct and indirect threats to coerce a reluctant party to actively participate in a particular racket.

- Complicity: this racket is similar to coercion, but the aim is not active enrolment in the racket, but rather passive compliance of someone who knows what is going on but is enrolled to say and do nothing.

- Con: this refers to complex rackets where the racketeer sells a story to enrol others on false pretenses that the enrolled person fully believes.

This chapter contextualises these rackets within an understanding of the interaction between economic policies, the dynamics of the polity and South Africa's challenging economic context. The core proposition is that the black political elite that gained control of the state after 1994 used political power to create the economic conditions 
of elite accumulation that may have reduced absolute poverty, but did little to reduce inequality. Learning from the way elites have always done business since colonial times, the new black elite replicated the rackets that were needed for this politically enabled mode of accumulation. Understanding this wider economic context is essential for making sense of state capture, and in particular how racketeers enrolled others into their increasingly sophisticated networks that eventually resulted in the repurposing of an entire set of state institutions during the Zuma era.

\subsection{CONTEXT}

South Africa has a population of 59 million and has been a democracy since 1994. It has a strong democratic constitution, a relatively mature institutional regulatory structure, a solid core of economic infrastructures and a market economy. Between the 1960s and 1980s, the South African economy diversified by expanding the manufacturing sector off the back of the mining and agricultural sectors. But following global trends from the early 1990s onwards, it was the growth of the financial sector that became a key driver of growth thus disincentivising diversification (Mohamed, 2010; Black \& Gerwel, 2014). Financialised growth exacerbates inequality and increases volatility.

According to the Gini coefficient, which measures income inequality, South Africa is one of the most unequal societies in the world (National Planning Commission, 2011). In 2018, more than $50 \%$ of its population lived below the poverty line, while $20 \%$ of its population could be classified as middle class and $5 \%$ as the elite (Chutel, 2018). Recent research on asset inequality based on data from two databases has reached an even more shocking conclusion about the class structure of South African society:

\section{... [B]oth sources agree that wealth inequality is extreme: ten percent of the population own more than 90 percent of all wealth while 80 percent have no wealth to speak of; a propertied middle class does not exist. (Orthofer, 2016)}

In addition to this, the 2017 Land Audit found that white South Africans owned 26.6 million of the 37 million hectares of land classified as farmland and agriculture holdings (72\%) in the country, while Africans who make up $80 \%$ of the population only owned $4 \%$ (a mere 1.4 million hectares). With that said, of the total land area of 121.9 million hectares, only 114 million hectares are registered as 'owned' by the Deeds Office (94\%). The state owns 14\% (17 million hectares) of this total. The difference between the land area $(121.9 \mathrm{~m} \mathrm{ha})$ and the registered land $(114 \mathrm{~m} \mathrm{ha})$ is 7.9 million hectares ( 5 times what Africans formally own). In short, $90 \%$ of the wealth is owned by $10 \%$ of the population, and $72 \%$ of the productive privately-owned farmland is owned by the minority (Department of Rural Development and Land Reform, 2017). Almost 
three decades into democracy land ownership patterns have remained the same. Growing service delivery protests and land occupation movements are increasingly the norm as racial polarisation and growing disillusion with the state intensifies.

Despite moderate growth between 1994 and 2007 and substantial real increases in fiscal expenditures to extend service provision (Swilling, Van Breda \& Van Zyl, 2008), unemployment and poverty have persisted. The official rate of unemployment, based on the 'narrow' definition, has not dipped below 25\%. Using a R524/month poverty line, $53 \%$ of the population lived in poverty in 1995, declining marginally to $48 \%$ by 2005 and remaining the upper forties since. This decline was attributed largely to the impact of social grants, which now benefit more people than the number of people in formal employment. It is worth mentioning that one in every three South Africans received a social grant in 2019. Many critical writers blame the failure of the state to initiate employment-creating industrial growth via structural transformation for the persistence of poverty and inequality since 1994 (Wolpe, 1995; Habib \& Padayachee, 2000; Bond, 2002; Gelb, 2006; Swilling, 2008; Hart, 2008; Mohamed, 2008, 2010; Freund \& Witt, 2010; Netshitenzhe, 2011; Marais, 2011; Khan, 2013; Khan \& Pillay, 2019). However, what exactly the portmanteau concept of 'structural transformation' (ST) means is rarely spelled out in any detail.

Regardless of this, the South African Government continues to formally define itself as a 'developmental state' committed to the structural transformation of the economy to deal with the legacy of apartheid (Republic of South Africa National Planning Commission, 2012). It aims to stimulate economic growth primarily by increasing public investment in national infrastructure to crowd in private sector co-investments. This is complemented by an inflation target of 3-6\%, a floating exchange rate, government deficits of 5-10\%, extensive fiscal expenditure on education, health and welfare, and incentives to promote raw material exports and expand the manufacturing sector. Despite all this, South Africa's economic growth rate is one of the lowest in Africa. For mainstream neo-classical economists, this is due to labour market rigidities, inflated government expenditures and energy shortages. While these are certainly a factor, the underlying resource drivers are as important, especially the rising cost of minerals, energy, water, waste and mobility (Swilling, Musango \& Wakeford, 2016).

Contrary to this, South Africa's key economic indicators post-1994 were a cause for optimism. Its average economic growth rate of $3.4 \%$ for the period $1994-2013$ was an improvement from the $1.4 \%$ for the period 1980-1993. By 2012, the country's national GDP was 77\% larger in real terms relative to 1994. Similarly, export growth per year increased from 2\% to 5\% between 1980 and 2000, cooling slightly to 4\% between 2001 and 2007. The South African economy has struggled to regain its early momentum 
during the post-2007/9 period. In 2015, economic growth slumped to little more than $1 \%$, and in 2016, growth limped in at $0.5 \%$. By 2019 , debt reached almost $69.1 \%$ of GDP (from about 26\% in 2008), the Rand continued its trend of depreciation - the nominal effective exchange rate of the Rand lost around $50 \%$ of its value between 2010 and 2017 - all culminating in the country's credit-rating being reduced to one notch above junk in 2017. Growth oscillated between $0.6 \%$ and $1.1 \%$ in 2017 and in April 2017 rating agency Standard \& Poor downgraded South Africa's credit rating to $\mathrm{BB}+$ or junk status. This provided the context for political struggles that brought the Zuma Presidency to an end between December 2017 (when Ramaphosa was elected ANC President) and February 2018 (which Zuma stepped down as President of the country).

Following others writing in the sustainability transition tradition (Swilling \& Annecke, 2012; Baker, Newell \& Phillips, 2014; Mark Swilling, 2020), the core structural problem of the South African economy is the dominant influence within the polity of the 'mineral-energy complex' (MEC) (Fine \& Rustomjee, 1996; Mohamed, 2010). The MEC refers to a coalition of interests that have a firm grip on energy production and extractive industries and their up- and downstream partners in the manufacturing sector. Up until 2009/10, this set of interests had well developed policy networks within the polity to protect their interests, legitimised by a carefully crafted 'transformation' (i.e., deracialisation) agenda. This explained the politics of socio-technical lock-in which ensured that South Africa continued to be committed to energy- and carbonintensive pathways and under-committed to supporting manufacturing subsectors that are not MEC-dependent (Black \& Gerwel, 2014). A purposive transition in these non-MEC sectors would require a substantial shift in the power relations within the polity to significantly reduce the policy leverage of the powerful mining and energy companies and in so doing respond to global landscape pressures relating to resource prices and competitiveness, the energy transition, as well as domestic labour strife. This would have meant establishing a radical new paradigm that Latin Americans refer to as 'post-extractivism' (Economic Commission for Latin America and the Carribean, 2013). The rootedness of key political interests within the MEC effectively made post-extravism a non-option for the post-1994 government.

At the core of South Africa's developmental failure is the fact that the negotiated settlement that took place between 1990 and 1994, after Mandela was released from prison, left the basic structure of economic power intact. Since 1994, black elites were incorporated into the share-owning class in return for maintaining the basic structure of economic power by limited state intervention in economic ownership and redistribution (Habib \& Padayachee, 2000; Hart, 2008; Glaser, 2011). Along the way, as described below, these black elites quickly learnt about the pre-existing rackets 
deployed by the white elites during the apartheid era, adjusting them to suit the new state-centric accumulation context in post-apartheid South Africa.

To rapidly stimulate growth and address inequalities, policy choices were made within the polity that reflected this power deal: neo-liberal ideologies were adopted (Hart, 2008), financialisation was promoted as a growth strategy (i.e., essentially debtfunded consumerism to expand the black middle class, ensuring that the financial sector grew faster than any other sector), capital flight for South African corporates (Mohamed, 2010) and non-developmental welfarism was implemented on a massive scale to quell popular unrest (Khan, 2013). Welfare grants increased from 3 million beneficiaries in 2000/2001 to 17 million in 2017 - from below 1\% of GDP to over $3.5 \%$ of GDP in a decade (Khan, 2013).

Following Bhorat, Cassim and Hirsch (2014, p. 4), South Africa exhibits all the features of a middle income growth trap, including an "overdependence on resourcebased foreign exchange for export revenues and short-term growth; a capital intensive path of industrialization; a consumption - rather than investment-driven - growth trajectory; reliance on state infrastructure for domestic growth, or simply a growth path built on sectors that are not employment-intensive".

This was the context for the recomposition of state apparatuses at the centre of the polity during the post-1994 era: with exceptions here and there (e.g., some housing, rural development and job-creation projects), instead of focusing on building new developmentally-oriented state institutions to drive a non-MEC employmentcreating 'developmental welfarism' (Khan, 2013), the focus was on replacing white with black officials as part of a state-driven 'new racial nationalism' agenda (Glaser, 2011). This strategy, coupled to debt-financed consumerism, stabilised the multiracial middle class base of the post-apartheid polity, but at the expense of what Khan calls the 'bioeconomy' - the bodies of the poor black majority and the resources of nature (Khan, 2013).

\subsection{ECONOMIC POLICY SINCE 1994}

It is arguable that South Africa has never had a national consensus on economic policy. The closest it came was the original Reconstruction and Development Programme (RDP). However, this was replaced by the Growth, Employment and Redistribution (GEAR) policy in 1996 - a policy that was imposed by the Minister of Finance with minimal consultation to promote 'macro-economic stabilisation' as financial conditions worsened. This was later upgraded and renamed ASGISA, which included a reference to 'binding constraints' that needed to be purposively addressed by state 
action to unleash economic potential. This was a marginal but significant shift from free market-oriented rationale of GEAR.

In the early 2000s, as the debt-financed consumer boom reached its limits, public sector funding of national infrastructure emerged as a substitute. This underpinned the adoption of the 'developmental state' discourse from 2002 onwards. It was this shift that brought into focus public sector investment resources such as those controlled by the Public Investment Corporation (PIC), Development Finance Institutions (DFIs) and State-Owned Entities (SOEs). This was followed later by the New Growth Path (NGP), and the National Development Plan (NDP). The former was driven mainly by the Department of Trade and Industry (DTI), but with little funding for the central tenet of this policy which was industrial policy. Industrial policy has never been a policy priority for the post-1994 governments. Despite promises given to the COSATU (The Congress of South African Trade Unions) by the NDP Commission that the rather weak economic chapter of the NDP would be revisited, this never happened. Trevor Manual claims this was because COSATU never came to the meetings. COSATU insists that this was an ideological move to avoid facing the challenge.

What followed during the Zuma years was 'radical economic transformation' and (later) references to 'inclusive growth' after Gigaba became Minister of Finance. Under Ramaphosa, we have the stimulus package, which is a mixed bag of short-term stimulus measures and longer-term structural change interventions. It is arguable that the inadequacy of both will result in an outcome that will be neither shortterm growth nor longer-term structural change. The Economic Strategy published by National Treasury in 2019 focused on a range of micro-economic interventions, some of which made a lot of sense (Economic Policy National Treasury, 2019). However, a coherent macro-economic framework was not provided, other than a commitment to austerity economics. The austerity-oriented Supplementary Budget released by the Minister of Finance in May 2020 put all the focus on managing down the expanding debt. A bold and ambitious macro-economic policy framework to guide high impact counter-cyclical interventions has never been attempted in the post-1994 era.

\subsection{FROM THE MBEKI TO ZUMA ERA ECONOMIC POLICIES}

During the Mbeki era, economic policy emphasised market-oriented strategies coupled to a BEE approach that linked emerging black business to contracts and deals with white business. This took place within a wider corporate-driven restructuring of the real economy. Three economic forces interacted in ways that undermined investments in the productive economy, namely financialisation, the shareholder value movement and BEE. Financialisation was about stimulating economic growth 
via consumer spending funded by the expansion of access to credit by the growing middle class and increasingly desperate working class. Shareholder value was about unbundling the conglomerates and increasing returns to shareholders. This resulted in a greater proportion of wealth accruing to shareholders than to labour during the post-1994 era. And finally, BEE resulted in the transfer of wealth from white to black shareholders and Managers. Together, financialisation, shareholder value and BEE undermined what South Africa needed most, namely an increase in investment in the productive economy. An increase in investments in the productive economy (guided by a coherent set of industrial policies) would have resulted in increased rather than reduced economic diversification, infrastructure investments that catalysed manufacturing and not mainly the primary extraction/export sectors, as well as a massive expansion of SMMEs (Small, Medium and Micro Enterprises). Financialisation, increasing shareholder value extraction and BEE transfers tend to be inconsistent with these kinds of real-economy investments (Mohamed, 2010).

Strategic refocusing (as required by the shareholder value movement - or following the slogan of the time: 'focus on your knitting') resulted in a massive increase in returns to shareholders which, in turn, undermined reinvestment. A total of R384bn was extracted by shareholders between 1999 and 2009, equal to $17 \%$ of gross fixed investment during this same period (Zalk, 2011, 2016). This was reinforced by transfers to BEE groups. An equally massive R317bn was transferred to black shareholders between 2000 and 2014, equal to $8 \%$ of gross fixed investment during this period (Zalk, 2016). While this may seem significant, it is worth noting that the number of black-owned and -controlled companies have precipitously fallen from an average of $7.1 \%$ for the period $1995-2000$ to a mere $0.5 \%$ of the JSE capitalisation in 2016 (Bosiu, Goga \& Roberts, 2017). These two sets of transfers (both underestimated here because they exclude transfers to external shareholders, and are only for specific periods) dis-incentivised reinvestment because of the need to service the debtbased equity of these groups. Debt-based buyouts of key SA manufacturers (such as ISCOR, Dorbyl, Scaw, etc.) by local and international companies limited investment in expansion because of the need to service the debt rather than reinvest in expansion (Roberts \& Rustomjee, 2009). Furthermore, international listings of South African companies promoted dis-investment rather than the much-promised capital raising for inward investment (Schneider, 2018). And debt-based expansion of consumption to de-racialise the middle class resulted in consumer growth rather than productionbased growth.

As this shareholder extraction and debt-funded consumer boom reached its limits in the early 2000s, Mbeki led the ideological shift from hardcore neo-liberalism to a 'developmental state' narrative that focused on what the ASGISA framework had 
already defined as 'binding constrains'. This may have brought an end to the obsession with privatisation of SOEs, but it did not translate into a full-blown Asian Tiger-type developmental state with the capacity to drive accelerated economic growth and development.

Instead of using the post-1994 moment to attack the unproductive structure of the economy, the Mbeki-led political coalition adopted economic policies that were inappropriate to direct the restructuring of the extractive institutions at the centre of corporate South Africa. They assumed that a remarkably simple (and with hindsight, naïve) mix of economic policies would provide the framework for macro-economic stabilisation and growth of a market-driven economy. These included inflation and public expenditure controls; removal of market 'distortions' such as tariffs, capital controls, excessive labour market protections and requirements to lend to particular sectors (to avoid inefficient rents); as well as a faith in foreign direct investment and the associated transfers of technology and management efficiencies (Habib \& Padayachee, 2000; Zalk, 2017). This economic cocktail was coupled to an equally simple equation of development with fiscal policy, resulting in a massive expansion in expenditures on welfare, housing, health and education (Freund, 2010).

The combination of market-oriented macro-economic stabilisation and developmentas-welfarism did not adequately address the problem of low investment levels caused by the way the profoundly extractive South African corporate structure was being transformed by a combination of shareholder value, BEE deals and financialisation. An alternative would have been state interventions that directly imposed conditionalities on these transactions. For example, BEE deals could have been conditional on reinvestments in industrial diversification; financialisation could have been conditional on financial institutions lending to support manufacturers and SMMEs; and shareholder value extraction could have been redirected by major players, such as the PIC, if it was required via legislation to be far more than just another investment fund.

Critics of the Mbeki era macro-economic policies argued that South African policy makers ignored the fact that public investments in other jurisdictions did not in fact displace private investment, but instead catalysed private investment. They also argued that the lowering of tariffs without industrial sector restructuring using industrial policy had proven unviable in other contexts (Zalk, 2017). Instead, developmental management and the allocation of rents needed a measure of protection until local industries were robust enough to compete internationally. Furthermore, critics argued that capital account stability was a good thing. Finally, critics argued that a stable well-paid workforce was preferable to an over-indebted underemployed poorly paid workforce, especially if economic growth depended on an enlarged the domestic 
consumer market. A general conclusion shared by many critics of the Mbeki era of neo-liberal reformism is that the state needed to actively lead corporate restructuring to ensure that investment in the real economy became the primary focus, rather than the extraction of dividends and rents for elite enrichment.

Although the adoption of the developmental state discourse in the early 2000s marked a realisation that the state needed to play a stronger leadership role in the economy, this translated into a narrow focus on infrastructure-led growth to draw in private investors rather than strategies to guide corporate restructuring and private sector investment into wider strategic industrial sectors.

By the time Thabo Mbeki was forced to resign as President, the ANC was facing the consequences of growing inequalities, persistent poverty and remarkably high unemployment levels. This prompted the ANC Youth League (ANCYL) to lead the way in calling for more 'radical economic transformation'. All talk of privatising SOEs fell away as SOEs came to be seen as key instruments for ratcheting up investment levels in the wake of the ongoing failure of the corporate sector to adopt a long-term, dividendoriented approach to investment. At the same time, there was growing dissatisfaction in the black business sector - the slow pace of accumulation in this sector was blamed on an over-dependence on the largesse of the white corporate sector.

\subsection{ZUMA ERA}

During the Zuma era, the focus shifted to the procurement spend of the SOEs as the primary vehicle for building a black industrial class. This had two consequences. Firstly, it reinforced a questionable assumption that capital intensive investments in large-scale infrastructures (i.e., 'capital deepening') leads to the type of growth and development that is needed. Capital intensive investments have a poor rand-to-job ratio (Rodrik, 2006). Secondly, it prepared the way for state capture as the shadow state networks came to broker the deal-making process that a focus on procurement spend opened. Within this context the rackets thrived.

The rise of the Zuma-led power elite can be understood in this context. The economic environment was already prepared by the adoption of the developmental state discourse introduced during the Mbeki era, coupled to an emphasis on infrastructureled growth, the need to expand BEE, the emerging significance of the SOEs (resulting from the 'developmental state' narrative) and a realisation that state-investment institutions like the PIC have real leverage. The conditions were ripe for an assertive power elite to repurpose state institutions in the name of addressing the contradictions of the Mbeki era. 
The solution Zuma's policy group offered was therefore unsurprising: heavy dependence on the use of the procurement systems of the SOEs. As articulated by the DTI from 2014 onwards, SOE procurement spend held the key to building a 'black industrial class' (Department of Trade and Industry, 2014). In reality, this meant re-purposing the SOEs to become the primary mechanisms for rent seeking at the interface between the constitutional and shadow states. This became the strategic focus of the power elite that formed around Zuma. To facilitate this, they needed brokers to help by-pass regulatory controls and shift money around (through local and international financial circuits) to finance deals as well as the transformation of the ANC into a compliant legitimating political machine. The Gupta networks emerged as the anointed brokers of this expanding rent seeking system. They were the grand masters of the dark arts of racketeering. They actively and systematically established an interlinked set of rackets across the apexes of key SOEs.

The difference between the economic policies of the Mbeki era neo-liberal reformers and the Zuma era revanchists lies in how the transition to democracy is understood. The institutions produced by this transition are associated with two different ways of doing politics. Mbeki's neo-liberal reformers were content to operate within the confines of the Constitution and were invested in institution building. That is, social and political transformation was deemed contingent on giving flesh to the socioeconomic rights mentioned in the Constitution by building state administrations able to work programmatically to achieve progressive policy outcomes. Building a capable state was their aim, including limiting corruption wherever possible - at least in theory. The rackets existed (e.g., the arms deal), but the repurposing of state institutions in favour of these rackets was not the dominant agenda.

Starting as a revolt against Thabo Mbeki, though not yet associated with a clear ideology, the Polokwane moment in 2007 gave rise to a new power elite that used the language of 'radical economic transformation' to bind together the new Zumacentred political coalition. Claiming to speak for 'ordinary people', those who are not well educated, who do not speak English well, who live in shacks or small towns and rural areas and who are excluded by the economy and the formal institutions of the state, this narrative gave rise to a politics profoundly mistrustful of the formal 'rules of the game', whether of the Constitution or legislation. The formal rules are rigged, this position proclaimed, in favour of whites and urban elites and against ordinary people. Radical Economic Transformation was thus presented as a programme that required changing - and frequently breaking - the rules, even those of the Constitution. The argument was compelling when viewed from the perspective of those who did not benefit significantly during the Mbeki era. More significantly, it was a license to unleash the rackets on a grand scale. At the centre of it all was an eminently believable 
lie: breaking the rules is a necessary condition for building a robust black industrial class to displace the dominance of 'white monopoly capital'.

\subsection{RACKETS FROM THE ZUMA ERA}

During the decade that started with the election of Jacob Zuma as President of the African National Congress in 2007 followed by his ascendance to the Presidency of the country in 2009, South Africa experienced a silent coup that led to what is generally referred to as 'state capture' (Chipkin \& Swilling, 2018). By the time he was elected, Zuma still faced 786 counts of bribery and had been questionably acquitted of rape in 2007 . He proceeded to lead, if not entirely orchestrate the labyrinthian project of state capture. This was a political project initiated by a power elite coordinated by an alliance of families, which included amongst others the Zuma family, the Watsons and the Gupta family - the latter consisting of a group of three brothers who moved to South Africa from India in the late 1990s. At the centre of this silent coup was a determined effort to implement what came to be referred to as the 'nuclear deal' that was struck between Zuma and Russia's President Putin in 2014. This should, however, be seen for what it was in the mind of Zuma and his advisors: the vanguard of an economic strategy to recompose the mineral-energy complex in the hands of a new black industrial class.

The Zuma-led power elite was loosely held together by a political project that depended on two means of violent control: the systemic use of violence to manage political dynamics (Von Holdt, 2013) and the reinforcement of misogynistic masculinities (Gqola, 2007; Kopano, 2008). Drawing on a rich tradition of writing about masculinity, it is clear that misogyny was enlisted together with violence to secure political control (Posel, 2005; Walker, 2005; Gqola, 2007; Morrell, 2007; Motsei, 2007; Kopano, 2008; Hunter, 2011; Morrell, Jewkes \& Lindegger, 2012; Ratele, 2014). The latter has been explored elsewhere (see Swilling, 2020, Chapter 9) and will not be further referred to here.

The nuclear deal with Putin (see Chapter 16) that Zuma drove hard to conclude and implement was effectively an agreement that South Africa would become a key element of Putin's global nuclear-based energy strategy, which aimed to break Russia's dependence on fossil fuels but was also a bid to mount a global alternative to renewable energy. For Zuma, this R1tn project was the crown jewel in his policy of 'radical economic transformation' aimed at creating a black industrial class that would displace the white capitalist elite. However, in order to implement the agreement, extra-legal means were required which, in turn, depended on state capture and the consolidation of a shadow state for managing the multiplicity of rackets required to 
enlist vast layers of across the state, politics, media and business. Over the course of 13 Cabinet reshuffles between 2009 and 2017, Zuma appointed 6 different Ministers of Energy, each with a renewed mandate to accelerate the nuclear build programme and, after 2014, to execute the nuclear deal.

To prepare for his global strategy, Putin signed a decree in 2007 that provided for the restructuring of the Russian nuclear industry that effectively integrated the entire value-chain into a single unified SOE (Merdan, 2018). Building on Russia's long Cold War history of nuclear armament (including the accumulation of vast technical know-how, large-scale nuclear infrastructures and uranium mining capabilities), this strategy to build a civilian nuclear energy sector made strategic sense. Rosatom was tasked with increasing nuclear energy in Russia's energy mix to $25 \%$ by 2030 , and in parallel it concluded agreements to build nuclear plants (including floating nuclear plants) in Egypt, Jordan, Algeria, UAE, Kuwait, India, Turkey, Thailand, Indonesia and a number of Eastern European countries (Merdan, 2018). Reports on Russian nuclear plants built outside Russia suggest they are a kind of hybrid between a military base and an embassy, underwritten by state guarantees that effectively gives Russia extensive control of these country's energy economies (Armstrong, 2015; Gallucci \& Shellenberger, 2017; Schepers, 2019). Russia's 2010 Energy Strategy document clearly stated that Russia's commitment to sustainable development means reducing dependence on fossil fuels by increasing the supply of nuclear energy (Safronova, 2010). Later drafts reinforced the commitment to nuclear-based sustainable development (Ministry of Energy of the Russian Federation, 2014). Nevertheless, as Eberhard and Lovins conclude, buying a Russian nuclear plant is an inadvisable high-risk venture:

\begin{abstract}
Russia is facing economic challenges, sliding in terms of rated world economies to number 15, below Mexico. Sovereign debt is a real concern and low oil prices and Western sanctions in response to Russia's aggression towards the Ukraine and other areas are making matters worse. ... Russia wants to build nuclear power plants and needs huge amounts of capital to finance its nuclear commitments around the world. It hardly appears to be a stable financial partner. (Eberhard \& Lovins, 2018)
\end{abstract}

In the shadows of the nuclear deal, in May 2010, a Gupta-owned company, Oakbay Resources and Energy, which included Zuma's son Duduzane Zuma as a shareholder via his company Mabengela Investments, quietly bought the Toronto-listed Uranium One's Dominion mine in Klerksdorp, located in the Northwest Province. The stateowned investment fund, the Public Investment Corporation, was hauled in to partly fund this transaction on suspect terms. The rationale was obvious: based on the assumption that an expansion of the nuclear energy sector was inevitable, the demand for uranium was set to skyrocket. The (largely illusory) foundations of a new supposedly black-owned mineral-nuclear-energy complex were being put in place 
by the power elite managing the symbiotic relationship between the shadow and constitutional state.

While recognising the endemic nature of corruption in the pre-democratic polity (Hyslop, 2005; Van Vuuren, 2006), Zuma's potentially productive strategy of using state intervention to build a national developmentally-oriented capitalist class (with many positive precedents elsewhere in the world, especially the 'Asian Tigers') was corrupted, as the resultant flow of rents got captured by an increasingly confident power elite clustered around President Zuma. Via a distinct set of rackets, the power elite captured the polity and repurposed state institutions by appointing loyalists to the Boards and Executives of key state-owned enterprises (e.g., Eskom, Transnet, Denel and many others) and strategic institutions (e.g., the South African Revenue Service [SARS] and security agencies). The result was the consolidation of neo-patrimonial governance (Pitcher, Moran \& Johnston, 2009; Lodge, 2014), with the constitutional state manipulated by what we called the 'shadow state' (Chipkin \& Swilling, 2018).

Two case studies reveal the direct connections between the Zuma-led power elite's political project and the disastrous economic consequences of this mode of neopatrimonial governance. Two international companies were prepared to risk their reputations to secure lucrative contracts with SOEs. The first case is the infrastructure and energy policy recommended by Bain \& Co directly to Zuma; and the second is the way Salim Essa strong-armed the CEO of T-Systems into a racket that allowed T-Systems to collude with state capture actors in order to land the IT contract for Transnet.

\subsubsection{Three Delusions of Bain \& Co's Grand Strategy}

Bain \& Co is a Boston-based global consulting firm. With a turnover of $\$ 4.8$ bn in 2019 , it is often counted as one of the 'big three' that dominates global consulting services. As described in Chapter 15 of this book, it was the focus of the Nugent Commission on Inquiry into the capture of SARS. Sometime in 2012, Bain \& Co started informal engagements with Zuma, presenting their extremely ambitious strategic proposals for directing the capital expenditure budgets of strategic SOEs under the direct authority of the President (Massone, 2018). Several presentations, most of which took place at the President's official residence in Pretoria, reinforced the unconstitutional impression that the Presidency could become the centre of strategic gravity for all SOE capital expenditures. Bain \& Co did a presentation for Zuma in March 2014, tellingly titled Reshaping South African economy [sic]: Discussion on a possible Central Procurement Service. Premised on the assumption that SOE procurement spend was R500bn at the time, Bain \& Co proposed the complete centralisation of all procurement via the creation of a "Central Procurement Agency" (CPA) that would 
report directly to the President (Bain \& Company, 2014a). Based on highly suspect estimates, Bain \& Co argued that this would enable a 10\% cost saving, equal to R50bn per annum. Following the classic consulting modus operandi designed to secure client compliance, the Bain \& Co consultants argued that this would require far-reaching institutional reorganisation to 'pay for itself'. This was the second delusion that Bain \& Co fed into South Africa's increasingly corrupt governance ecosystem.

The first delusion was presented a year earlier on 25 April 2013. In a presentation titled Infrastructure Development in South Africa: Holistic approach to infrastructure development - initial considerations, Bain \& Co presented what they called an "organizational solution to improve infrastructure delivery". Citing examples from Dubai, Malaysia, Shenzhen and Dublin, and using SAA as a potential success case, Bain \& Co recommended the establishment of the SA Infrastructure Delivery Agency (SAIDA) to coordinate national infrastructure planning. The "benefits" were presented as "central control", "leverages the private sector" and makes "[o]ptimal use of limited overall funding pool and scarce human capabilities". SAIDA's role would be to ensure "strategic alignment", "process re-design", "financial control", "supervising of project budgets" and would have the "power to intervene in cases of failure and move to central execution model" (Bain \& Company, 2013). With the CPA and the SAIDA reporting directly to the President, this would have given the Zuma-led power elite complete control of the R500bn procurement spend.

The third delusion was the presentation of an energy solution that would have catapulted South Africa back into a global technological dark age. In essence, just as global investments in renewables were accelerating and nuclear fleets were being wound down, Bain \& Co recommended a national energy strategy based on nuclear power and fracked gas. In a presentation titled Sirius Program - reshaping South Africa's Energy sector [sic]: Discussion Document presented on June 2014, Bain \& Co presented proposals for how to " $[\mathrm{t}]$ ransform Eskom", "solve short and medium term energy capacity/mix challenge" and "redefine energy ecosystem/governance". To "transform Eskom", Bain \& Co recommended a "new leadership" (which led to the appointment of Brian Molefe), more "immediate funding" from the fiscus, an "Eskom turnaround" plan and the resolution of the Medupi and Kusile overspend which was described as a "national security matter". To address the short and medium capacity challenge, Bain \& Co recommended investing in Coal 3 (another mega-coal fired power station) and the Inga hydro scheme (despite 20 years of planning for this that has resulted in nothing), a joint venture (JV) between Eskom and PetroSA to "aggressively pursue shale gas", and "launch [of] nuclear development". The long-term plan was to unbundle and privatise generation, but to "maintain state ownership" of transmission. Bain \& Co estimated that R330bn would be needed to implement this plan, resulting in GDP growth of $5.4 \%$ by 2025 . This excluded the cost of the so-called 
"new build" programme which Bain \& Co estimated would cost between R638 and R833bn made up as follows: Coal 3 (4.8 GW at R120bn), renewables (1-3 GW uncosted), Inga hydro (2.5 GW - uncosted), shale gas (8-14.4 GW at R106-R190bn), nuclear (7.4-13.8 GW at R326-R608bn) plus a 15\% contingency. In short, an energy future based on coal, shale gas and nuclear (Bain \& Company, 2014b). To motivate this archaic vision, and contrary to all the available empirical evidence, it was argued that nuclear would cost less per MWh than wind and solar CSP over the long term solar PV was not included in the analysis.

Bain \& Co injected these three grand delusions into South Africa's body politic at exactly the moment when the Zuma-led power elite was commencing the implementation phase of its strategy to repurpose state institutions. Significantly, they were presented as a strategy to 'reshape the economy'. Mountains of empirical evidence now exists to show how procurement spend was intentionally hijacked to promote the interests of a narrow power elite in the name of 'building a black industrial class'. The next case reveals how this was done.

\subsubsection{T-Systems Aids and Abets State Capture: How the Racket Works in Practice}

T-Systems is a German-based global IT company that employs 45000 people. Its turnover in 2015 was $€ 8.6 \mathrm{bn}$. Gert Schoonbee (2017), a self-declared patriotic Afrikaner, was Managing Director of T-Systems South Africa in 2012 when T-Systems was awarded Transnet's IT contract. It was a 5-year contract with an option of a 2-year extension ending in 2019. However, this contract was only awarded after Schoonbee agreed to abide by terms of a collusion racket laid down by Salim Essa, close business associate of the Gupta family. The terms were that either agrees to transferring a top slice of the contract to Essa's company, or T-Systems agrees to sub-contract a list of BEE companies that Essa provided. Schoonbee selected the latter because he could fool himself into believing he was not directly guilty of corrupt behaviour. The companies were Zestilare (Essa's wife had a share in this company), GSS, Sechaba, Vumela and Ngwete. Schoonbee knew these companies would then provide the kickbacks required by Essa. To make this racket work, the contracts with the BEE subcontractors stipulated that T-Systems staff to be deployed into the subcontractors to manage the work. After the Betrayal of the Promise report was released in May 2017, Schoonbee ordered a forensic audit of the subcontractors after which T-Systems terminated the contracts with the subcontractors. The T-Systems staff deployed into the subcontractors returned to T-Systems and just continued to do what they had always done while seemingly 'employed' by the subcontractors (Schoonbee, 2017). In other words, this collusion racket included the believable lie that it empowered BEE companies, but in reality it was 'fronting' of an extreme kind. 
Replicate the T-Systems racket many thousands of times over and it becomes very clear how these typically South African rackets drain resources from productive activity. The rackets are deeply entrenched because convincing and believable lies are told to justify the implementation of a seemingly patriotic benefit, namely to black economic empowerment. The role of international companies in aiding and abetting these rackets has gained increasing attention in recent years (some of which are discussed in this book).

The construction of a shadow state is effectively the archetypal neo-patrimonial form of governance. It entails the restructuring of the polity: the constitutional state remains intact, albeit hollowed out by the rackets, and interacts symbiotically with a shadow state comprised of a powerful network of powerbrokers who manage extralegal rackets sanctioned by the patron-in-chief (Zuma).

None of this would have been possible without the deployment of violent practices which, in turn, limited the rights promised by democracy. Von Holdt has analysed how the use of violence during elections, violent settling of disputes within organisations, political assassinations and the violent subversion of the rule of law by democratic institutions generates and shapes violence, while providing a certain level of constraint on violence (Von Holdt, 2013). The result was the emergence of an institutionalised "violent democracy" (ibid., p. 602) after 1994 that abetted the construction of the increasingly authoritarian neo-patrimonial mode of governance after 2009.

Despite the assault on constitutional democracy, not all state institutions were compromised. Despite evidence of corruption of the lower levels of the judiciary, the judiciary as a whole - often prompted by the Office of the Public Protector - became a bulwark against state capture. The fate of the nuclear deal is a case in point. Under the leadership of two women anti-nuclear activists, Liz McDade and Makoma Lekalakala, ${ }^{1}$ two NGOs - Earthlife Africa and the South African Faith Communities Environmental Institute (SAFCEI) - instigated a court case in 2015 against the President, Minister of Energy and other government bodies, challenging the legality of the signed Inter-Governmental Agreement (IGA) between Russia and South Africa (Chutel, 2018). To everyone's surprise, the court ruled in favour of the applicants in 2017 and the nuclear deal was effectively scrapped.

Significantly, the court noted that the IGA included wide-ranging binding provisions that did not appear in any of Russia's IGAs with other countries. Specifically, "the IGA provides for a strategic partnership, which would focus on the development of a comprehensive nuclear new-build programme, including the design, creation and 
decommissioning of nuclear plants; use of the Russian Water-Water Energetic Reactor (VVER) technology for a total capacity of $9.6 \mathrm{GW}$; collaborating on implementing two units of $2.4 \mathrm{GW}$ at specifically stated sites and with additional IGAs to be signed on how this would be done, with joint committees to oversee this; favourable tax regimes and other incentives provided for Russia; and with South Africa incurring all liability as a result of any nuclear incidents." (Prins \& Davies, 2018) The court ruled that the wide-ranging nature of these provisions were such that Parliament was legally obliged to "approve" the IGA - instead, ignoring the advice of the State Law Advisor, the Minister of Energy at the time only tabled the IGA in Parliament for "noting" (Prins \& Davies, 2018). The National Treasury's criticism of the financial provisions of the deal were also ignored, including public statements to the effect that South Africa's national sovereignty was at risk.

The only way to understand why the authors of the (originally secret) ${ }^{2}$ IGA had mistakenly over-reached their legal mandate is to recognise how Zuma had effectively consented that South Africa would become a pawn in Russia's new post-2007 grand strategy to become a global nuclear power. In return for subverting the much-lauded South African Constitution, there is evidence the Russians funded the ANC's election campaigns and inserted key intelligence operatives into the Presidency to bring the deal to closure (Bhorat, Buthelezi, Chipkin, Duma, Mondi, Peter, Qobo, Swilling \& Friedenstein, 2017).

\subsection{BEYOND ZUMA}

After nearly 8 years in power, a broad-based coalition of civil society, business, faith and human rights organisations coalesced around a demand for Zuma's resignation and a (notional) return to constitutionalism. In December 2017, the governing party voted to replace President Zuma with Cyril Ramaphosa as President of the ANC. After Zuma resisted pressures to resign to buy time to finalise the nuclear deal (Swilling, 2019), he eventually 'resigned' as President of the country in February 2018, and Ramaphosa replaced him. One of the first acts of Ramaphosa's new Minister of Energy, Jeff Radebe, was to sign 27 renewable energy contracts that the previous President put on hold to prepare the way for the finalisation of the nuclear deal. Ramaphosa informed the World Economic Forum in January 2018 that nuclear was not affordable and there were rumours that Putin tried to strong-arm him into respecting the terms of the IGA. The Department of International Relations/Foreign affairs (DIRCO) had to send a high-ranking official to Moscow to explain the South African case, much to

2 Vladimir Slivyak, head of Ecodefence, a Moscow-based NGO, found the 'secret' IGA lodged on the website of the Russian foreign ministry and he conveyed it to Earthlife Africa in Johannesburg, which made the court application possible. 
the displeasure of the Russians. Ramaphosa, however, may support renewable energy (with evidence that his personal investment fund has renewable energy investments), but given his history (as Secretary-General of the National Union of Mineworkers), he is also a strong supporter of the coal industry, describing it in his maiden speech as a "sunrise industry" without referring to renewables despite the remarkable growth of renewables in SA since 2011. However, in his 2019 State of the Nation address he corrected this, referring to climate change and renewable energy investments. His Minister of Finance reinforced this in his Budget speech a few weeks later. In September 2019, the President sent a message to the UN Climate Summit confirming his support for a Just Energy Transition (Ramaphosa, 2019).

Ramaphosa has re-established constitutional governance by ensuring that new leadership is appointed across the board, from SARS to the NPA, criminal justice system and the SOE Boards and CEOs. However, this does not mean the rackets have disappeared. There is a constant stream of evidence that the rackets are alive and thriving. They may no longer enjoy the legitimation of the Ramaphosa-centred power elite, but they continue to morph into the new environment. The so-called 'fight back campaign' by the self-proclaimed 'radical economic transformation' forces effectively masks the re-positioning of one set of rackets; while another set of racket-based networks emerge to extract rents in more subtle and sophisticated ways. This emerges when one looks closely at who is behind the push to re-introduce nuclear power and the related proposals to introduce a new gas infrastructure (with reports that this is linked to Russian interests) - this includes the group that self-identifies with the South African Energy Forum (for example, Advil Nchabeleng) and various networks coalescing around the Department of Mineral Resources and Energy (DMRE) that share an interest in promoting nuclear. Undoubtedly, gas will play a key role as backup for a post-coal renewables-based energy system, but this would be, at most, $10 \%$ of total energy supply.

\subsection{CONCLUSION}

Although all South Africa's economic policies proclaim laudable commitments to reducing inequality, unemployment and poverty by stimulating economic growth, in reality sustained economic growth was not achieved over time. Even if it was, the type of economic growth was not driven by fundamental shifts in the structure of economic power. Instead, the post-1994 black elite used state power to create the conditions for elite accumulation rather than a redistribution-driven mode of economic development. During the Mbeki era, economic growth was stimulated by financialisation, BEE transfers and shareholder value extraction rather than productive investments in the real economy. 
Like most neo-liberal macro-economic policy frameworks, the GEAR and ASGISA economic policy frameworks envisaged a limited role for the state in promoting significant levels of redistribution (notwithstanding the reference to 'binding constraints' in the latter policy framework). This created the conditions for Zuma's rise to power on a populist ticket, with a promise to deploy the state for developmental purposes. The rackets during the post-1994 period were there, but they never became a central organising principle of the Mbeki-led power elite. This changed during the Zuma era when state resources and interventions were directly used to build a 'black industrial class'. Disguised behind the language of 'radical economic transformation', economic policies were adopted that simplistically defined the procurement spend of the SOEs as the most decisive strategic lever of redistributive economic change. Although in theory it all made sense, in practice, under Zuma, the rackets were licensed to proliferate on a grand scale, with key brokers - such as the Guptas and Watsons playing key enabling roles. The end result was not 'radical economic transformation', but economic stagnation, looting, worsening inequalities, rising unemployment and increased poverty. 


\section{References}

Armstrong, I. (2015) 'Russia is creating a global nuclear power empire', Global Risk Insights. [Online]. https://bit.ly/3jQlxKH (Accessed 5 August 2020).

Bain \& Company (2013) 'Support Document to Vittorio Massone Affidavit (vm12): Project Elephant - New Development Agency', Nugent Commission.

Bain \& Company (2014a) 'Support Document to Vittorio Massone Affidavit (vm14): Central Procurement Agency (CPA), Nugent Commission.

Bain \& Company (2014b) 'Support Document to Vittorio Massone Affidavit (vm18): Project Sirius - Eskom', Nugent Commission.

Baker, L., Newell, P. \& Phillips, J. (2014) 'The Political Economy of Energy Transitions: The Case of South Africa', New Political Economy, 19(6):1-28. https://doi.org/10.1080/13563 467.2013 .849674

Bhorat, H., Buthelezi, M., Chipkin, I., Duma, S., Mondi, L., Peter., C., Qobo, M., Swilling, M. \& Friedenstein, H. (2017) Betrayal of the Promise: How South Africa is being stolen, State Capacity Research Project. South Africa. [Online] https://bitly/2X93QhC

Bhorat, H., Cassim, A. \& Hirsch, A. (2014) Policy co-ordination and growth traps in a middle-income country setting: The case of South Africa, United Nations University, World Institute for Development Economics Research (WIDER). 2014/155. Cape Town. [Online].https://doi.org/10.35188/UNUWIDER/2014/876-6

Black, A. \& Gerwel, H. (2014) 'Shifting the growth path to achieve employment intensive growth in South Africa', Development Southern Africa, 31(2):241-256. https:// doi.org/10.1080/0376835X.2013.871198

Bond, P. (2002) Unsustainable South Africa: Environment, Development and Social Protest. London: Pluto Press.

Bosiu, T., Goga, S. \& Roberts, S. (2017) 'Concentration, proofits and investment: Let's focus on the structure of the economy, not "cash hoarding", Centre for Competition, Regulation and Economic Development (CCRED). Johannesburg: Centre for
Competition, Regulation and Economic Development. [Online]. https://bit.ly/ 2Xc9HCZ

Chipkin, I. \& Swilling, M. (2018) Shadow State: The Politics of Betrayal. Johannesburg: Wits University Press. https://doi. org/10.18772/22018062125

Chutel, L. (2018) 'How two South African women stopped Zuma and Putin's $\$ 76$ billion Russian nuclear deal', Quartz Africa, 25 April.

Cornwall, A., Corrêa, S, \& Jolly, S. (eds.) Development with a Body: Sexuality, Human Rights and Development. London: Zed Books, pp. 121-135.

Department of Rural Development and Land Reform (2017) Land Audit Report Phase II: Private Land Ownership by Race, Gender and Nationality, Department of Rural Development and Land Reform, Pretoria. [Online]. https://bit.ly/3An3DWu (Accessed 11 August 2020).

Department of Trade and Industry (2014) The DTI to create 100 Black industrialists in three years, South African Government. [Online]. https://bit.ly/3s1TDPd (Accessed 13 August 2020)

Eberhard, A. \& Lovins, A. (2018) 'Five facts that prive South Africa's nuclear power plan should die', The Conversation, 31 January.

Economic Commission for Latin America and the Carribean (2013) Natural Resources: Status and trends towards a regional development agenda in Latin America and the Caribbean. Santiago: United Nations.

Economic Policy National Treasury (2019) 'Economic transformation, inclusive growth, and competitiveness: Towards an Economic Strategy for South Africa', National Treasury. Pretoria. [Online]. https://bit.ly/3CwMP1c (Accessed 13 August 2020).

Fine, B. \& Rustomjee, Z. (1996) The Political Economy of South Africa: From MineralsEnergy Complex to Industrialization. Boulder, Co.: Westview Press.

Freund, B. (2010) 'Development Dilemmas in Post-Apartheid South Africa: An Introduction', in B. Freund \& H. Witt (eds.) Development Dilemmas in Post-Apartheid 
South Africa. Durban: University of KwaZuluNatal Press, pp. 1-32.

Freund, B. \& Witt, H. (2010) Development Dilemmas in Post-Apartheid South Africa. Durban: University of KwaZulu-Natal Press.

Gallucci, N. \& Shellenberger, M. (2017) 'Will the West Let Russia Dominate the Nuclear Market?', Foreign Affairs. [Online]. https:// fam.ag/3Cr0Mxx (Accessed 5 August 2020).

Gelb, S. (2006) 'A South African Developmental State: What is Possible?', in Harold Wolpe Memorial Trust's Tenth Anniversary Colloquium 'Engaging silences and unresolved issues in the political economy of South Africa', 21-23 September, Cape Town, Unpublished.

Glaser, D. (2011) 'The New Black/African Racial Nationalism in South Africa: Towards a Liberal-Egalitarian Critique, Transformation, 76:67-94. https://doi.org/10.1353/trn.20 11.0029

Gqola, P. (2007) 'How the "cult of femininity" and violent masculinities support endemic gender based violence in contemporary South Africa, African Identities, 5(1):111-124. https://doi. org/10.1080/14725840701253894

Habib, A. \& Padayachee, V. (2000) 'Economic Policy and Power Relations in South Africa's Transition to Democracy', World Development, 28(2):245-263. https://doi. org/10.1016/S0305-750X(99)00130-8

Hart, G. (2008) 'The provocations of Neoliberalism: contesting the nation and liberation after Apartheid, Antipode, 40(4):678-705. https://doi.org/10.1111/ j.1467-8330.2008.00629.x

Hunter, M. (2011) 'Beneath the "Zunami”' Jacob Zuma and the gendered politics of social reproduction in South Africa', Antipode, 43(4):1102-1126. https://doi.org/10.11 11/j.1467-8330.2010.00847.x

Hyslop, J. (2005) 'Political Corruption: Before and After Apartheid', Journal of Southern African Studies, 31(4):773-789. https://doi. org/10.1080/03057070500370555

Khan, F. (2013) 'Poverty, grants, revolution and "real Utopias": society must be defended by any and all means necessary!, Review of African Political Economy, 40(138):572-588. https://doi.org/10.1080/03056244.20 13.854035

Khan, F. \& Pillay, P. (2019) 'Corruption and its Repercussions on Employment, Poverty and Inequality: Rwanda and South Africa Compared, Journal of Reviews on Global Economics, 8(0):1203-1212. https://doi. org/10.6000/1929-7092.2019.08.104

Kopano, R. 2008. 'Ruling Masculinities in Post-Apartheid South Africa', in S. Corrêa (ed.) Development with a Body: Sexuality, Human Rights and Development. Zed Books, pp. 121-135. https://bit.ly/31I7mtr

Lodge, T. (2014) 'Neo-patrimonial politics in the ANC', African Affairs, 113(450):1-23. https://doi.org/10.1093/afraf/adt069

Marais, H. (2011) 'South Africa pushed to the limit: the political economy of change', The Political Economy of Change, p. 536. https:// doi.org/10.1111/1478-9302.12000_116

Massone, V. (2018) 'Nugent Commission: Vittorio Massone Affidavit', Nugent Commission, Pretoria.

Merdan, E. (2018) 'New enregy export strategy: Russia's shift to nuclear energy', Energy, 9 April.

Ministry of Energy of the Russian Federation (2014) 'Draft Energy Strategy of the Russian Federation until 2035', ESCAP Policy Documents Management. [Online]. https:// bit.ly/37HnZxr (Accessed 13 August 2020).

Mohamed, S. (2008) 'Financialization and Accumulation in South Africa, Unpublished Powerpoint presentation, 7 April 2008. Johannesburg: Corporate Strategy and Industrial Development, University of the Witwatersrand.

Mohamed, S. (2010) 'The State of the South African Economy Development or Decline?', New South African Review, 1:39-64. https:// doi.org/10.18772/22010115164.6

Morrell, R. (2007) 'Men, masculinities and gender politics in South Africa: a reply to Macleod', Psychology in Society, 35 (1):15-26.

Morrell, R., Jewkes, R. \& Lindegger, G. (2012) 'Hegemonic Masculinity/Masculinities in South Africa: Culture, Power, and Gender Politics', Men and Masculinities, 15(1):11-30. https://doi.org/10.1177/1097184X12438001 
Motsei, M. (2007) The Kanga and the Kangaroo Court. Johannesburg: Jacana.

National Planning Commission (2011) Diagnostic Overview. Pretoria: National Planning Commission, Republic of South Africa.

Netshitenzhe, J. (2011) 'The state of the South Africa state', 10th Harold Wolpe Memorial Lecture, Cape Town.

Orthofer, A. (2016) 'Wealth Inequality in South Africa: Insights from Survey and Tax Data', REDI3X3 Working Paper 15, Cape Town.

Pitcher, A., Moran, M.H. \& Johnston, M. (2009) 'Rethinking Patrimonialism and Neopatrimonialism in Africa', African Studies Review, 52(01):125-156. https://doi.org/ 10.1353/arw.0.0163

Posel, D. (2005) 'The scandal of manhood: "Baby rape" and the politicization of sexual violence in post-apartheid South Africa', Culture, Health and Sexuality, 7(3):239-252. https:// doi.org/10.1080/13691050412331293467

Prins, N. \& Davies, E. (2018) South Africa's nuclear new-build programme: who are the players and what are the potential strategies for pushing the nuclear new-build programme? Cape Town: World Wide Fund for Nature (WWF).

Ramaphosa, C. (2019) 'Statement by H.E. President Cyril Ramaphosa of South Africa to the United Nations Secretary-General's Climate Summit, 23 September 2019', thepresidency.gov. [Online]. https://bitly/ 3itxmH5 (Accessed 7 September 2020).

Ratele, K. (2014) 'Currents against gender transformation of South African men: Relocating marginality to the centre of research and theory of masculinities', Norma, 9(1):30-44. https://doi.org/10.1080/18902 138.2014 .892285

Republic of South Africa National Planning Commission (2012) National Development Plan. Pretoria: Republic of South Africa.

Roberts, S. \& Rustomjee, Z. (2009) 'Industrial policy under democracy: apartheid's grown-up infant inductries? Iscor and Sasol,' Transformation, 71:50-75. https://doi. org/10.1353/trn.0.0044
Rodrik, D. (2006) Understanding South Africa's Economic Puzzles, Paper prepared for the Harvard Center for International Development Project on South Africa. Cambridge, MA: John F. Kennedy School of Government, Harvard University.

Safronova, G. (2010) Energy Strategy of Russia for the period up to 2030. Moscow: Ministry of Energy of the Russian Federation.

Schepers, N. (2019) 'Russia’s Nuclear Energy Exports: Status, Prospects and Implications', EUNon-Proliferation and Disarmament Consortium, p. 61.

Schneider, G.E. (2018) 'The Post-Apartheid Development Debacle in South Africa: How Mainstream Economics and the Vested Interests Preserved Apartheid Economic Structures', Journal of Economic Issues, 52(2):306-322. https://doi.org/10.1080/ 00213624.2018.1469855

Schoonbee, G. (2017) Interview with Gert Schoonbee, June.

Swilling, M. (2008) ‘Tracking South Africa’s Elusive Developmental State', Administratio Publico, 16(1):1-29. Cape Town: HSRC Press.

Swilling, M. (2019) 'Zexit, a nuclear deal and Russia’s strong-arm persuasion', Daily Maverick, 8 January.

Swilling, M. (2020) The Age of Sustainability: Just Transitions in a Complex World. London: Routledge.

Swilling, M. \& Annecke, E. (2012) Just Transitions: Explorations of Sustainability in an Unfair World. Tokyo: United Nations University Press.

Swilling, M., Musango, J. \& Wakeford, J. (2016) Greening the South African Economy. Cape Town: Juta.

Swilling, M., Van Breda, J. \& Van Zyl, A. (2008) 'Contextualising social giving: an analysis of state fiscal expenditure and poverty in South Africa, 1994-2004', in A. Habib \& B. Maharaj (eds.) Social Giving in South Africa. Cape Town: HSRC Press.

Van Vuuren, H. (2006) Apartheid Grand Corruption: Assessing the scale of crimes of profit in South Africa from 1976 to 1994', 
Security Studies. Pretoria: Institute for Security Studies.

Von Holdt, K. (2013) 'South Africa: the transition to violent democracy', Review of African Political Economy, 40(138):589-604. https://doi.org/10.1080/03056244.20 13.854040

Walker, L. (2005) 'Men behaving differently: South African men since 1994', Culture, Health and Sexuality, 7(3):225-238. https:// doi.org/10.1080/13691050410001713215

Wolpe, H. (1995) 'The uneven transition from apartheid in South Africa', Transformation, 27:88-102.

Zalk, N. (2011) 'South African Post-Apartheid Policies Towards Industrialization: Tentative
Implications for Other African Countries', in A. Norman, K. Botchwey, H. Stein \& J.E. Stiglitz (eds.) Good Growth and Governance in Africa: Rethinking Development Strategies. Oxford: Oxford Scholarship Online, pp. 345-371. https://doi.org/10.1093/acprof:oso/ 9780199698561.001 .0001

Zalk, N. (2016) 'Selling off the silver: The imperative for productive and jobs-rich investment', New Agenda, (63).

Zalk, N. (2017) 'Industrial policy in a harsh climate: The case of South Africa, in Transforming Economics, pp. 327-354. https://doi.org/10.1016/B978-0-08100262-9.00012-4 



\section{APPENDIX}

\begin{tabular}{|c|c|c|c|c|}
\hline $\begin{array}{l}\text { Case Study } \\
\text { in State } \\
\text { Capture }\end{array}$ & Status & Summary Description & $\begin{array}{l}\text { Investigation } \\
\text { Body / } \\
\text { Source of } \\
\text { Evidence }\end{array}$ & $\begin{array}{l}\text { Government } \\
\text { Entity } \\
\text { Implicated }\end{array}$ \\
\hline \multicolumn{5}{|c|}{ Scandals Connected to Jacob Zuma, Guptas, Other Key Networks and ANC Politics } \\
\hline $\begin{array}{l}\text { The State } \\
\text { of Capture } \\
\text { report - } \\
\text { focuses } \\
\text { on Guptas' } \\
\text { relationship } \\
\text { with Jacob } \\
\text { Zuma and } \\
\text { their alleged } \\
\text { influence on } \\
\text { the affairs } \\
\text { of state }\end{array}$ & $\begin{array}{l}\text { First complaint } \\
\text { was received } \\
\text { in March } 2016 \\
\text { and the report } \\
\text { was released in } \\
\text { November } 2016 .\end{array}$ & $\begin{array}{l}\text { Investigation into complaints of alleged improper } \\
\text { and unethical conduct by the President and } \\
\text { other State Functionaries, relating to alleged } \\
\text { improper relationships and involvement of the } \\
\text { Gupta Family in the removal and appointment } \\
\text { of Ministers and Directors of State-Owned } \\
\text { Enterprises (SOEs), resulting in improper and } \\
\text { possibly corrupt award of State Contracts and } \\
\text { Benefits to the Gupta Family's Businesses. } \\
\text { The report details numerous allegations of } \\
\text { the Guptas' involvement in affairs of the state } \\
\text { and their irregular activities that enable rent } \\
\text { extraction. The findings were not conclusive } \\
\text { and the remedial action was to establish a } \\
\text { commission of inquiry into state capture (to } \\
\text { be appointed by the President, but with a } \\
\text { judge selected by the Chief Justice). Litigation } \\
\text { endeavoured to delay or prohibit the report's } \\
\text { release and implementation of remedial actions, } \\
\text { but failed, and the commission was established } \\
\text { in } 2018 \text {. }\end{array}$ & $\begin{array}{l}\text { - Public } \\
\text { Protector, } \\
\text { followed by } \\
\text { litigation }\end{array}$ & $\begin{array}{l}\text { - } \text { GCIS (The } \\
\text { New Age) } \\
\text { - Eskom } \\
\text { (Optimum) } \\
\text { - Transnet } \\
\text { (Regiments/ } \\
\text { Trillian) } \\
\text { - Denel } \\
\text { - SAA (The } \\
\text { New Age) } \\
\text { - SABC (The } \\
\text { New Age) } \\
\text { - Department of } \\
\text { Finance } \\
\text { - Transport } \\
\text { (SAA) } \\
\text { - Communica- } \\
\text { tions (SABC } \\
\text { \& GCIS) }\end{array}$ \\
\hline $\begin{array}{l}\text { Zondo } \\
\text { Commission }\end{array}$ & $\begin{array}{l}\text { Established } \\
\text { in 2018, with } \\
\text { anticipated } \\
\text { conclusion being } \\
\text { the end of } 2021 \text {. }\end{array}$ & $\begin{array}{l}\text { Formally titled the Judicial Commission of } \\
\text { Inquiry into Allegations of State Capture, } \\
\text { Corruption and Fraud in the Public Sector } \\
\text { including Organs of State, the Commission } \\
\text { was promulgated by then President Zuma in } \\
\text { response to the remedial actions as outlined in } \\
\text { the Public Protector's State of Capture report. } \\
\text { As of June } 2021 \text {, the Commission that started } \\
\text { in August } 2018 \text { has held more than } 418 \text { days } \\
\text { of hearings of over } 330 \text { testimonies (generating } \\
\text { over } 71000 \text { pages of transcript). The inquiry's } \\
\text { terms of reference were expansive and, as } \\
\text { such, the scope of investigations went beyond } \\
\text { merely looking into the Gupta-related cases, } \\
\text { covering other networks (e.g., Bosasa) as well } \\
\text { as other government institutions (e.g., role } \\
\text { of Parliament). }\end{array}$ & $\begin{array}{l}\text { - Zondo } \\
\text { Commission }\end{array}$ & $\begin{array}{l}\text { Various } \\
\text { work-streams } \\
\text { covering } \\
\text { inter alia: } \\
\text { - SOEs } \\
\text { (Eskom, } \\
\text { Transnet, } \\
\text { Denel, SAA) } \\
\text { - Free State } \\
\text { Provincial } \\
\text { Government } \\
\text { - Bosasa } \\
\text { - SARS } \\
\text { - Law } \\
\text { enforcement } \\
\text { - State Security } \\
\text { Agency (SSA) } \\
\text { - The New Age } \\
\text { \& ANN7 } \\
\text { - Role of } \\
\text { Parliament } \\
\text { and ANC }\end{array}$ \\
\hline
\end{tabular}




\begin{tabular}{|c|c|c|c|c|}
\hline $\begin{array}{l}\text { Case Study } \\
\text { in State } \\
\text { Capture }\end{array}$ & Status & Summary Description & $\begin{array}{l}\text { Investigation } \\
\text { Body / } \\
\text { Source of } \\
\text { Evidence }\end{array}$ & $\begin{array}{l}\text { Government } \\
\text { Entity } \\
\text { Implicated }\end{array}$ \\
\hline \multicolumn{5}{|c|}{ Scandals Connected to Jacob Zuma, Guptas, Other Key Networks and ANC Politics } \\
\hline Bosasa & $\begin{array}{l}\text { Dating back to a } \\
2009 \text { SIU report. } \\
\text { Investigations and } \\
\text { various litigations } \\
\text { are ongoing. }\end{array}$ & $\begin{array}{l}\text { In 2019, former Bosasa C00, Anglo Agrizzi, } \\
\text { testified at the Zondo Commission, detailing } \\
\text { the acts and long history of corruption between } \\
\text { various Bosasa companies predominantly } \\
\text { owned by Gavin Watson, and numerous } \\
\text { government entities/departments. The } \\
\text { testimony of Agrizzi (and other former Bosasa } \\
\text { employees) corroborated the findings of a } \\
2009 \text { SIU investigation that alleged corruption } \\
\text { in several contracts Bosasa had with the } \\
\text { Department of Correctional Services. Criminal } \\
\text { court proceedings have been initiated based } \\
\text { on the 2009 SIU investigation, along with new } \\
\text { investigations initiated by SARS and other law } \\
\text { enforcement entities. }\end{array}$ & $\begin{array}{l}\text { - Special } \\
\text { Investi- } \\
\text { gation } \\
\text { Unit (SIU) } \\
\text { - Zondo } \\
\text { Commission }\end{array}$ & $\begin{array}{l}\text { - Department of } \\
\text { Correctional } \\
\text { Services } \\
\text { - Department of } \\
\text { Justice } \\
\text { - Department of } \\
\text { Home Affairs } \\
\text { - Department of } \\
\text { Transport } \\
\text { - Various SOEs } \\
\text { (e.g., SAPO, } \\
\text { ACSA) } \\
\text { - National } \\
\text { Prosecuting } \\
\text { Authority } \\
\text { (NPA) } \\
\text { - Members of } \\
\text { Parliament }\end{array}$ \\
\hline Arms Deal & $\begin{array}{l}\text { Various } \\
\text { investigations and } \\
\text { sources, dating } \\
\text { back to 1990s. } \\
\text { Most significant } \\
\text { source being } \\
\text { through Seriti } \\
\text { Commission. } \\
\text { Corruption case } \\
\text { against Zuma is } \\
\text { ongoing. }\end{array}$ & $\begin{array}{l}\text { Commission of Inquiry into allegations of fraud, } \\
\text { corruption, impropriety, or irregularity in the } \\
\text { Strategic Defence Procurement Packages } \\
\text { (SDPP). Various court cases related to } \\
\text { allegations of corruption against Jacob Zuma. } \\
\text { On Monday, } 24 \text { October 2011, the President } \\
\text { announced the Commission chaired by Judge } \\
\text { Seriti. The findings of the Commission were that } \\
\text { there was "no evidence" of corruption, but this } \\
\text { is seen by many to have been a whitewash. The } \\
\text { report was taken on review and set aside in } \\
\text { August 2019. The corruption case against Zuma } \\
\text { is ongoing before the courts. }\end{array}$ & $\begin{array}{l}\text { - Seriti } \\
\text { Commission } \\
\text { - Various } \\
\text { court cases }\end{array}$ & $\begin{array}{l}\text { Initially: } \\
\text { - South African } \\
\text { National } \\
\text { Defence } \\
\text { Force } \\
\text { - Members of } \\
\text { Parliament } \\
\text { Allegations also } \\
\text { involve: } \\
\text { - NPA } \\
\text { - SSA }\end{array}$ \\
\hline $\begin{array}{l}\text { Nkandla } \\
\text { Security } \\
\text { Upgrades }\end{array}$ & $\begin{array}{l}\text { Investigation } \\
\text { started in } \\
\text { November } 2012 \text {. } \\
\text { Report on } \\
\text { investigation } \\
\text { was released in } \\
\text { March } 2014 \text {. }\end{array}$ & $\begin{array}{l}\text { Report on security upgrades to President } \\
\text { Zuma's homestead in Nkandla. The investigation } \\
\text { found that the President unduly benefited from } \\
\text { the upgrades and as part of remedial actions } \\
\text { the President was required to pay back a portion } \\
\text { of the costs of the upgrades. Zuma instructed } \\
\text { that SAPS undertake their own investigation, } \\
\text { which sought to rationalise the expenses (fire- } \\
\text { pool report). Parliament accepted this alternative } \\
\text { report, but major court cases followed, } \\
\text { ultimately declaring that the Public Protector's } \\
\text { remedial actions are binding. President and } \\
\text { Parliament failed to uphold the Constitution. } \\
\text { President ordered to "pay back the money". }\end{array}$ & $\begin{array}{l}\text { - Public } \\
\text { Protector's } \\
\text { Secured } \\
\text { in Comfort } \\
\text { report, } \\
\text { followed by } \\
\text { litigation }\end{array}$ & $\begin{array}{l}\text { - Department of } \\
\text { Public Works } \\
\text { - South African } \\
\text { Police Service }\end{array}$ \\
\hline
\end{tabular}




\begin{tabular}{|c|c|c|c|c|}
\hline $\begin{array}{l}\text { Case Study } \\
\text { in State } \\
\text { Capture }\end{array}$ & Status & Summary Description & $\begin{array}{l}\text { Investigation } \\
\text { Body / } \\
\text { Source of } \\
\text { Evidence }\end{array}$ & $\begin{array}{l}\text { Government } \\
\text { Entity } \\
\text { Implicated }\end{array}$ \\
\hline \multicolumn{5}{|c|}{ Scandals Connected to Jacob Zuma, Guptas, Other Key Networks and ANC Politics } \\
\hline $\begin{array}{l}\text { Private } \\
\text { Aircraft } \\
\text { Landing at } \\
\text { Waterkloof } \\
\text { Airforce Base } \\
\text { and Gupta } \\
\text { Sun City } \\
\text { Wedding }\end{array}$ & May 2013. & $\begin{array}{l}\text { In 2013, justice, crime prevention, and } \\
\text { security cluster (JCPS) - a cabinet structure } \\
\text { composed of various ministries - undertook an } \\
\text { investigation into the Landing of a Commercial } \\
\text { aircraft at Air Force Base Waterkloof (report } \\
\text { titled the same). The investigation revealed that } \\
\text { the Guptas initially tried to organise a special } \\
\text { landing at OR Tambo International Airport, but } \\
\text { was turned down. They then approached the } \\
\text { Indian High Commission who re-designated the } \\
\text { wedding entourage as an official delegation to } \\
\text { secure a landing at the Waterkloof base. The } \\
\text { wedding held at Sun City was attended by a } \\
\text { number of high-profile ANC politicians and was } \\
\text { paid for in part by moneys looted from the Vrede } \\
\text { Dairy Farm project. }\end{array}$ & $\begin{array}{l}\text { - Report by } \\
\text { JPCS } \\
\text { - Zondo } \\
\text { Commission }\end{array}$ & $\begin{array}{l}\text { - Department of } \\
\text { International } \\
\text { Relations and } \\
\text { Cooperation } \\
\text { (DIRCO) } \\
\text { - Department of } \\
\text { Defence } \\
\text { - Department of } \\
\text { Transport }\end{array}$ \\
\hline $\begin{array}{l}\text { Free State } \\
\text { Provincial } \\
\text { Capture, } \\
\text { includes } \\
\text { Vrede Dairy } \\
\text { Farm and } \\
\text { Asbestos } \\
\text { Contracts }\end{array}$ & Ongoing. & $\begin{array}{l}\text { The Vrede Dairy Farm project was initiated } \\
\text { by the Free State Provincial Government as a } \\
\text { development project, however, in partnering with } \\
\text { a Gupta-linked company Estina, government } \\
\text { funds were looted. In 2018, the Public } \\
\text { Protector released a report on their } 2018 \\
\text { investigation, but it was taken on review and } \\
\text { set aside by the courts. The second part of the } \\
\text { investigation is yet to be finalised. The NPA } \\
\text { laid criminal charges against Gupta associates } \\
\text { and implicated government officials. Court } \\
\text { proceedings are ongoing. } \\
\text { Significant testimony and evidence have been } \\
\text { presented at the Zondo Commission regarding } \\
\text { the Vrede Farm case, as well as the asbestos } \\
\text { inspection project (criminal proceedings are also } \\
\text { underway). Both projects implicate high-profile } \\
\text { politicians and senior officials manipulating } \\
\text { government process. }\end{array}$ & $\begin{array}{l}\text { - Public } \\
\text { Protector } \\
\text { reports } \\
\text { - Zondo } \\
\text { Commission } \\
\text { - Various } \\
\text { court cases }\end{array}$ & $\begin{array}{l}\text { - Free State } \\
\text { Provincial } \\
\text { Government }\end{array}$ \\
\hline $\begin{array}{l}\text { Irregular } \\
\text { removal of } \\
\text { National } \\
\text { Director } \\
\text { of Public } \\
\text { Prosecutions } \\
\text { (NDPP), } \\
\text { Mxolisi } \\
\text { Nxasana }\end{array}$ & $\begin{array}{l}\text { Inquiry instituted } \\
\text { in February } 2015, \\
\text { but was cancelled } \\
\text { in May } 2015 . \\
\text { This triggers the } \\
\text { Constitutional Court } \\
\text { cases that followed. }\end{array}$ & $\begin{array}{l}\text { Inquiry into the fitness of Mxolisi Nxasana to } \\
\text { hold office as NDPP. The Inquiry was cancelled } \\
\text { after Zuma "agreed to let Nxasana resign". He } \\
\text { was paid R17m - the balance of his ten-year } \\
\text { contract. Court cases followed detailing the } \\
\text { abuse of the presidency powers by Zuma. } \\
\text { Ultimately, Nxasana was ordered to repay } \\
\text { R17m and Zuma's appointed replacement, } \\
\text { Shawn Abrahams, was ordered to vacate office. } \\
\text { Constitutional Court found Zuma's actions to } \\
\text { be an abuse of power and in breach of his } \\
\text { constitutional obligations. }\end{array}$ & $\begin{array}{l}\text { - Cassim } \\
\text { Inquiry into } \\
\text { fitness of } \\
\text { Mxolisi } \\
\text { Nxasana to } \\
\text { hold office } \\
\text { of NDPP } \\
\text { initiated } \\
\text { by Zuma, } \\
\text { followed by } \\
\text { litigation }\end{array}$ & $\begin{array}{l}\text { - National } \\
\text { Prosecution } \\
\text { Authority }\end{array}$ \\
\hline $\begin{array}{l}\text { Political } \\
\text { killings in } \\
\text { KZN }\end{array}$ & $\begin{array}{l}\text { Established in } \\
\text { October } 2016 . \text { The } \\
\text { report was released } \\
\text { in May } 2018 .\end{array}$ & $\begin{array}{l}\text { On } 28 \text { October 2016, the Premier of the } \\
\text { Province of KwaZulu-Natal established a } \\
\text { Commission of Enquiry into the Underlying } \\
\text { Causes of the Murder of Politicians in KwaZulu- } \\
\text { Natal (KZN). }\end{array}$ & $\begin{array}{l}\text { - Moerane } \\
\text { Commission } \\
\text { of Enquiry }\end{array}$ & $\begin{array}{l}\text { - KZN Provincial } \\
\text { Government } \\
\text { - KZN Local } \\
\text { Governments }\end{array}$ \\
\hline
\end{tabular}




\begin{tabular}{|c|c|c|c|c|}
\hline $\begin{array}{l}\text { Case Study } \\
\text { in State } \\
\text { Capture }\end{array}$ & Status & Summary Description & $\begin{array}{l}\text { Investigation } \\
\text { Body / } \\
\text { Source of } \\
\text { Evidence } \\
\end{array}$ & $\begin{array}{l}\text { Government } \\
\text { Entity } \\
\text { Implicated }\end{array}$ \\
\hline \multicolumn{5}{|c|}{ Scandals Connected to Jacob Zuma, Guptas, Other Key Networks and ANC Politics } \\
\hline \multicolumn{5}{|c|}{ State Capture of State-Owned Enterprises and Government Departments } \\
\hline $\begin{array}{l}\text { Interference } \\
\text { in operations } \\
\text { at the SABC }\end{array}$ & $\begin{array}{l}\text { The Ad Hoc } \\
\text { Committee was } \\
\text { established in } \\
\text { November } 2016 \\
\text { and final report } \\
\text { was tabled on } \\
24 \text { February } 2017 .\end{array}$ & $\begin{array}{l}\text { Parliamentary Ad Hoc Committee on the } \\
\text { SABC Board Inquiry into mismanagement and } \\
\text { interference in SABC operations. Findings } \\
\text { include evidence of Minister Faith Muthambi's } \\
\text { interference in the organisation and editorial } \\
\text { interference, in the firing of SABC } 8 \text { who } \\
\text { protested censorship of the national broadcaster } \\
\text { (on instruction from COO Hlaudi Motsoeneng). It } \\
\text { should be noted that the inquiry was preceded } \\
\text { by an investigation by the Public Protector. } \\
\text { Details are contained in the } 2014 \text { report titled } \\
\text { When Governance and Ethics Fail. }\end{array}$ & $\begin{array}{l}\text { - Parliamen- } \\
\text { tary Inquiry } \\
\text { - Preceded by } \\
\text { an investi- } \\
\text { gation by } \\
\text { the Public } \\
\text { Protector }\end{array}$ & $\begin{array}{l}\text { - SABC } \\
\text { (Department } \\
\text { of Communi- } \\
\text { cation) }\end{array}$ \\
\hline \multirow[t]{2}{*}{$\begin{array}{l}\text { Passenger } \\
\text { Rail Agency } \\
\text { of South } \\
\text { Africa } \\
\text { (PRASA) }\end{array}$} & $\begin{array}{l}\text { Complaints were } \\
\text { lodged in } 2012 \\
\text { and the report } \\
\text { was released in } \\
\text { August } 2015 .\end{array}$ & $\begin{array}{l}\text { Several cases of "mismanagement and } \\
\text { irregularities" regarding various contracts. } \\
\text { Lucky Montana was CEO at the time. One of } \\
\text { the remedial actions stipulated that National } \\
\text { Treasury was to investigate all PRASA contracts } \\
\text { from } 2012 \text { onwards with a value of R10 million } \\
\text { or more. National Treasury implemented the } \\
\text { remedial action which resulted in several } \\
\text { investigations, the details of which were leaked } \\
\text { to the public. }\end{array}$ & $\begin{array}{l}\text { - Public } \\
\text { Protector's } \\
\text { Derailed } \\
\text { report on } \\
\text { PRASA } \\
\text { - Numerous } \\
\text { investiga- } \\
\text { tions }\end{array}$ & $\begin{array}{l}\text { - PRASA } \\
\text { - Department of } \\
\text { Transport }\end{array}$ \\
\hline & $\begin{array}{l}\text { In June } 2017, \\
\text { Parliament directed } \\
4 \text { committees to } \\
\text { investigate state } \\
\text { capture. Committee } \\
\text { hearings were not } \\
\text { completed. }\end{array}$ & $\begin{array}{l}\text { In terms of the parliamentary directive, the } \\
\text { Portfolio Committee on Transport was requested } \\
\text { to establish an Inquiry into State Capture at } \\
\text { PRASA. However, the Portfolio Committee noted } \\
\text { that PRASA was not mentioned in the Public } \\
\text { Protector's State of Capture report and decided } \\
\text { they would focus on the various investigation } \\
\text { reports produced for National Treasury (as } \\
\text { recommended in Derailed report). }\end{array}$ & $\begin{array}{l}\text { - Portfolio } \\
\text { Committee } \\
\text { on Transport }\end{array}$ & $\begin{array}{l}\text { - PRASA } \\
\text { - Department of } \\
\text { Transport }\end{array}$ \\
\hline $\begin{array}{l}\text { Eskom } \\
\text { Inquiry into } \\
\text { State Capture }\end{array}$ & $\begin{array}{l}\text { In June } 2017 \text {, } \\
\text { Parliament directed } \\
4 \text { committees } \\
\text { to investigate } \\
\text { state capture. } \\
\text { Public Enterprises } \\
\text { Committee } \\
\text { report on Eskom } \\
\text { was released in } \\
\text { November } 2018 .\end{array}$ & $\begin{array}{l}\text { Extensive hearings were held by the Committee } \\
\text { detailing much of the evidence presented in } \\
\text { the Public Protector's report. The Committee } \\
\text { presented recommendations and compiled } \\
\text { a final report detailing their findings. These } \\
\text { included findings that Ministers Lynne Brown } \\
\text { and Malusi Gigaba were negligent and had to } \\
\text { be held accountable. Also recommended that } \\
\text { criminal investigations be undertaken against } \\
\text { the relevant Eskom executives. }\end{array}$ & $\begin{array}{l}\text { - Parliamen- } \\
\text { tary Inquiry }\end{array}$ & $\begin{array}{l}\text { - Eskom } \\
\text { - Department } \\
\text { of Public } \\
\text { Enterprises }\end{array}$ \\
\hline $\begin{array}{l}\text { Nugent } \\
\text { Commission } \\
\text { - SARS } \\
\text { Inquiry }\end{array}$ & $\begin{array}{l}\text { The Inquiry was } \\
\text { constituted on } \\
24 \text { May } 2018 \text { and } \\
\text { the final report } \\
\text { was released in } \\
\text { December } 2018 .\end{array}$ & $\begin{array}{l}\text { Commission of Inquiry into tax administration } \\
\text { and governance by South African Revenue } \\
\text { Service (SARS). Tom Moyane was fired based on } \\
\text { the interim report released in September } 2018 . \\
\text { The inquiry found that Moyane, with the help of } \\
\text { consultancy company Bain, had implemented } \\
\text { restructuring of the organisation, resulting in } \\
\text { gross mismanagement and erosion of SARS. } \\
\text { Moyane motivated the restructuring based on } \\
\text { the "rogue unit" narrative that has been the } \\
\text { subject of several other debunked investigations } \\
\text { and the subject of much litigation. }\end{array}$ & $\begin{array}{l}\text { - Judicial } \\
\text { Commission } \\
\text { of Inquiry } \\
\text { - Court cases } \\
\text { around the } \\
\text { "rogue unit" } \\
\text { narrative }\end{array}$ & $\begin{array}{l}\text { - SARS } \\
\text { (National } \\
\text { Treasury) }\end{array}$ \\
\hline
\end{tabular}




\begin{tabular}{|c|c|c|c|c|}
\hline $\begin{array}{l}\text { Case Study } \\
\text { in State } \\
\text { Capture }\end{array}$ & Status & Summary Description & $\begin{array}{l}\text { Investigation } \\
\text { Body / } \\
\text { Source of } \\
\text { Evidence }\end{array}$ & $\begin{array}{l}\text { Government } \\
\text { Entity } \\
\text { Implicated }\end{array}$ \\
\hline \multicolumn{5}{|c|}{ Scandals Connected to Jacob Zuma, Guptas, Other Key Networks and ANC Politics } \\
\hline \multicolumn{5}{|c|}{ State Capture of State-Owned Enterprises and Government Departments } \\
\hline $\begin{array}{l}\text { Commission } \\
\text { of Inquiry } \\
\text { into Public } \\
\text { Investment } \\
\text { Corporation } \\
\text { (PIC) }\end{array}$ & $\begin{array}{l}\text { In October } 2018 \text {, } \\
\text { the Commission } \\
\text { was constituted, } \\
\text { and the final report } \\
\text { was released in } \\
\text { March } 2020 .\end{array}$ & $\begin{array}{l}\text { Commission of Inquiry into allegations of } \\
\text { impropriety regarding Public Investment } \\
\text { Corporation (PIC). There were extensive hearings } \\
\text { on various 'dodgy' deals the PIC entered } \\
\text { into and details of political and executive } \\
\text { interference in the operations and decision- } \\
\text { making processes of the investment agency. }\end{array}$ & $\begin{array}{l}\text { - Judicial } \\
\text { Commission } \\
\text { of Inquiry }\end{array}$ & $\begin{array}{l}\text { - PIC (National } \\
\text { Treasury) }\end{array}$ \\
\hline $\begin{array}{l}\text { South African } \\
\text { Social } \\
\text { Security } \\
\text { Agency } \\
\text { (SASSA) }\end{array}$ & $\begin{array}{l}\text { Various } \\
\text { Constitutional Court } \\
\text { cases from } 2011 \\
\text { to } 2018 \text { resulted } \\
\text { in removal of CPS } \\
\text { as service provider } \\
\text { to SASSA. }\end{array}$ & $\begin{array}{l}\text { In 2014, South African Social Security Agency's } \\
\text { (SASSA) } 2012 \text { contract with CPS was found } \\
\text { to be irregular and invalid, however, due to the } \\
\text { importance of ensuring beneficiaries received } \\
\text { grants, CPS continued to be the service } \\
\text { providers until } 2018 \text {. Following a March } 2017 \\
\text { ruling, the Constitutional Court instituted a } \\
\text { Section } 38 \text { Inquiry into Minister Bathabile } \\
\text { Dlamini's personal liability for the narrowly } \\
\text { averted grant payment crisis. }\end{array}$ & $\begin{array}{l}\text { Primary } \\
\text { sources: } \\
\text { - AllPay court } \\
\text { case } \\
\text { - Black Sash } \\
\text { court case }\end{array}$ & - SASSA \\
\hline $\begin{array}{l}\text { South African } \\
\text { Airways (SAA) } \\
\text { and SAA } \\
\text { Technical }\end{array}$ & $\begin{array}{l}\text { Court case } \\
\text { to have Dudu } \\
\text { Myeni declared a } \\
\text { delinquent director } \\
\text { was launched } \\
\text { in } 2017 .\end{array}$ & $\begin{array}{l}\text { Court case was launched in } 2017 \text { by Outa and } \\
\text { the SAA Pilots' Association (SAAPA) to declare } \\
\text { Myeni a delinquent director in terms of the } \\
\text { Companies Act, based on her actions while she } \\
\text { was chairperson of the SAA Board. In 2020, the } \\
\text { High Court declared Myeni a delinquent director } \\
\text { for life. A significant amount of new evidence } \\
\text { also emerged through the Zondo Commission, } \\
\text { outlining how the operations at SAA were } \\
\text { undermined and how Myeni and others abused } \\
\text { their positions of authority. }\end{array}$ & $\begin{array}{l}\text { - Court } \\
\text { papers } \\
\text { - Zondo } \\
\text { Commission }\end{array}$ & $\begin{array}{l}\text { - SAA } \\
\text { - SAA Technical }\end{array}$ \\
\hline $\begin{array}{l}\text { Gupta Family } \\
\text { Naturalisation }\end{array}$ & $\begin{array}{l}\text { In June } 2017, \\
\text { Parliament directed } \\
4 \text { committees to } \\
\text { investigate state } \\
\text { capture. Final } \\
\text { report was tabled } \\
14 \text { March } 2019 .\end{array}$ & $\begin{array}{l}\text { Portfolio Committee on Home Affairs Inquiry into } \\
\text { the Gupta Family Naturalisation was established } \\
\text { in terms of the Parliamentary directive. Hearings } \\
\text { formally started on } 12 \text { September 2018. Final } \\
\text { report was tabled on } 14 \text { March 2019. Questions } \\
\text { were raised around contracts with Visa } \\
\text { Facilitation Services. This matter is ongoing as } \\
\text { of December } 2020 \text {. }\end{array}$ & $\begin{array}{l}\text { - Portfolio } \\
\text { Committee } \\
\text { on Home } \\
\text { Affairs }\end{array}$ & $\begin{array}{l}\text { - Department of } \\
\text { Home Affairs }\end{array}$ \\
\hline $\begin{array}{l}\text { Inquiry into } \\
\text { State Capture } \\
\text { related to } \\
\text { Gupta-owned } \\
\text { mines }\end{array}$ & $\begin{array}{l}\text { In June } 2017, \\
\text { Parliament directed } \\
4 \text { committees } \\
\text { to investigate } \\
\text { state capture. }\end{array}$ & $\begin{array}{l}\text { Though the Committee drafted a term of } \\
\text { reference for the Inquiry, the activities of holding } \\
\text { hearings and consolidating the evidence never } \\
\text { materialised beyond questions being put to then } \\
\text { Minister Zwane. }\end{array}$ & $\begin{array}{l}\text { - Portfolio } \\
\text { Committee } \\
\text { on Mineral } \\
\text { Resources }\end{array}$ & $\begin{array}{l}\text { - Department } \\
\text { of Mineral } \\
\text { Resources }\end{array}$ \\
\hline
\end{tabular}




\begin{tabular}{|c|c|c|c|c|}
\hline $\begin{array}{l}\text { Case Study } \\
\text { in State } \\
\text { Capture }\end{array}$ & Status & Summary Description & $\begin{array}{l}\text { Investigation } \\
\text { Body / } \\
\text { Source of } \\
\text { Evidence } \\
\end{array}$ & $\begin{array}{l}\text { Government } \\
\text { Entity } \\
\text { Implicated }\end{array}$ \\
\hline \multicolumn{5}{|c|}{ Scandals Connected to Jacob Zuma, Guptas, Other Key Networks and ANC Politics } \\
\hline \multicolumn{5}{|c|}{ State Capture of State-Owned Enterprises and Government Departments } \\
\hline \multirow{3}{*}{$\begin{array}{l}\text { Various } \\
\text { investigations } \\
\text { relating to } \\
\text { State Capture } \\
\text { at Eskom }\end{array}$} & 2015 & $\begin{array}{l}\text { In } 2015 \text {, Dentons produced an interim report } \\
\text { on their investigations into Status of Business } \\
\text { and Challenges at Eskom. Their investigation } \\
\text { was halted. }\end{array}$ & - Eskom & - Eskom \\
\hline & \multirow[t]{2}{*}{2017} & $\begin{array}{l}\text { In 2017, PricewaterhouseCoopers (PwC) was } \\
\text { appointed by National Treasury to investigate } \\
\text { Eskom's Coal Procurement Processes. Damning } \\
\text { findings were made in relation to Gupta-owned } \\
\text { Tegeta mine contracts and poor coal quality. }\end{array}$ & - Eskom & - Eskom \\
\hline & & $\begin{array}{l}\text { G9 was contracted by Eskom to investigate } \\
\text { the Trillian/McKinsey contracts. Interim report } \\
\text { presented to Board of Eskom in August } 2017 . \\
\text { The investigation remained incomplete, and } \\
\text { no report is available in the public domain. } \\
\text { Evidence from the investigation was presented } \\
\text { in the Parliamentary Inquiry into Eskom } \\
\text { State Capture. }\end{array}$ & $\begin{array}{l}\text { - National } \\
\text { Treasury }\end{array}$ & - Eskom \\
\hline $\begin{array}{l}\text { National } \\
\text { Treasury } \\
\text { Fundudzi } \\
\text { reports, } \\
\text { related to } \\
\text { Eskom and } \\
\text { Transnet }(x 3) \\
\end{array}$ & $\begin{array}{l}\text { Final reports } \\
\text { compiled in } \\
\text { November } 2018 \\
\text { and released to } \\
\text { the public shortly } \\
\text { thereafter. }\end{array}$ & $\begin{array}{l}\text { Investigations requested by National Treasury } \\
\text { of alleged corruption at Transnet and Eskom. } \\
\text { The three reports focused on Eskom (general), } \\
\text { the contracts related to Trillian/McKinsey and } \\
\text { Transnet Locomotives. }\end{array}$ & $\begin{array}{l}\text { - National } \\
\text { Treasury } \\
\text { Fundudzi }\end{array}$ & $\begin{array}{l}\text { - Eskom } \\
\text { - Transnet }\end{array}$ \\
\hline \multirow[t]{2}{*}{$\begin{array}{l}\text { Transnet } \\
\text { Locomotive } \\
\text { Contracts }\end{array}$} & \multirow[t]{2}{*}{$\begin{array}{l}\text { Investigations } \\
\text { commenced in } \\
\text { December } 2017 \\
\text { and reports on } \\
\text { findings submitted } \\
\text { during } 2018 .\end{array}$} & $\begin{array}{l}\text { Werksmans Attorneys was appointed in } \\
\text { December } 2017 \text { to undertake an investigation } \\
\text { into the } 1064 \text { Transnet Locomotives } \\
\text { procurement process, however, the investigation } \\
\text { was halted. No report in the public domain. }\end{array}$ & - Werksmans & - Transnet \\
\hline & & $\begin{array}{l}\text { Mncedisi Ndlovu \& Sedumedi (MNS) Attorneys } \\
\text { was then appointed to investigate } 1064 \\
\text { locomotives procurement process. The report } \\
\text { is not in the public domain, but media indicates } \\
\text { that recommendations mirror the Werksmans' } \\
\text { findings and recommends that Molefe face } \\
\text { criminal charges. }\end{array}$ & $\begin{array}{l}\text { - Mncedisi } \\
\text { Ndlovu \& } \\
\text { Sedumedi }\end{array}$ & - Transnet \\
\hline $\begin{array}{l}\text { Inquiry into } \\
\text { State Capture } \\
\text { at Transnet } \\
\text { and Denel }\end{array}$ & $\begin{array}{l}\text { In June } 2017, \\
\text { Parliament directed } \\
4 \text { committees to } \\
\text { investigate state } \\
\text { capture. Committee } \\
\text { hearings were not } \\
\text { completed. }\end{array}$ & $\begin{array}{l}\text { A detailed information booklet was prepared } \\
\text { in relation to Transnet, however, hearings were } \\
\text { not held before the end of term of Parliament. } \\
\text { Following National elections in } 2019 \text {, it } \\
\text { was decided that outstanding Inquiries into } \\
\text { state capture be postponed indefinitely until } \\
\text { conclusion of the Zondo Commission. }\end{array}$ & $\begin{array}{l}\text { - Portfolio } \\
\text { Committee } \\
\text { on Public } \\
\text { Enterprises }\end{array}$ & $\begin{array}{l}\text { - Transnet } \\
\text { - Denel }\end{array}$ \\
\hline
\end{tabular}




\begin{tabular}{|c|c|c|c|c|}
\hline $\begin{array}{l}\text { Case Study } \\
\text { in State } \\
\text { Capture }\end{array}$ & Status & Summary Description & $\begin{array}{l}\text { Investigation } \\
\text { Body / } \\
\text { Source of } \\
\text { Evidence }\end{array}$ & $\begin{array}{l}\text { Government } \\
\text { Entity } \\
\text { Implicated }\end{array}$ \\
\hline \multicolumn{5}{|c|}{ Scandals Connected to Jacob Zuma, Guptas, Other Key Networks and ANC Politics } \\
\hline \multicolumn{5}{|c|}{ Law Enforcement and the Security Cluster } \\
\hline $\begin{array}{l}\text { Enquiry into } \\
\text { Jiba and } \\
\text { Mrwebi's } \\
\text { fitness to } \\
\text { hold office } \\
\text { at NPA }\end{array}$ & $\begin{array}{l}\text { Established in } \\
\text { November } 2018 . \\
\text { Report was issued } \\
\text { in April } 2019 .\end{array}$ & $\begin{array}{l}\text { Presidential Enquiry into the fitness to hold } \\
\text { office of suspended NPA senior advocates } \\
\text { Nomgcobo Jiba and Lawrence Mrwebi. NPA's } \\
\text { deputy head Jiba, and Mrwebi, the head of } \\
\text { the Specialised Commercial Crimes Unit, were } \\
\text { suspended in October } 2018 \text { by President Cyril } \\
\text { Ramaphosa. The Inquiry was headed by retired } \\
\text { Constitutional Court Justice Yvonne Mokgoro. } \\
\text { Jiba and Mrwebi were accused of improper } \\
\text { conduct in their handling of cases involving } \\
\text { former crime intelligence head Richard Mdluli, } \\
\text { as well as former KwaZulu-Natal Hawks boss } \\
\text { Johan Booysen. }\end{array}$ & $\begin{array}{c}\text { - Mokgoro } \\
\text { Enquiry }\end{array}$ & $\begin{array}{l}\text { - } \text { National } \\
\text { Prosecuting } \\
\text { Authority }\end{array}$ \\
\hline $\begin{array}{l}\text { High-Level } \\
\text { Review Panel } \\
\text { on the State } \\
\text { Security } \\
\text { Agency (SSA) }\end{array}$ & $\begin{array}{l}\text { Established in June } \\
2018 \text { and final } \\
\text { report was sent to } \\
\text { the President in } \\
\text { December } 2018 .\end{array}$ & $\begin{array}{l}\text { The High-Level Review Panel into the SSA } \\
\text { was established by President Ramaphosa in } \\
\text { June 2018. The key finding was a serious } \\
\text { politicisation and factionalisation of the } \\
\text { intelligence community over the past decade } \\
\text { or more. This resulted in "an almost complete } \\
\text { disregard for the Constitution, policy, legislation } \\
\text { and other prescripts, and [turned] our civilian } \\
\text { intelligence community into a private resource } \\
\text { to serve the political and personal interests of } \\
\text { particular individuals" (High-Level Review Panel } \\
\text { on the SSA, 2018, p.ii). }\end{array}$ & $\begin{array}{l}\text { - Review } \\
\text { Panel } \\
\text { established } \\
\text { by President } \\
\text { Ramaphosa }\end{array}$ & - SSA \\
\hline $\begin{array}{l}\text { Various court } \\
\text { cases against } \\
\text { persons } \\
\text { within law } \\
\text { enforcement }\end{array}$ & Ongoing. & $\begin{array}{l}\text { Though testimony and evidence have been } \\
\text { presented at the Zondo Commission, it is } \\
\text { understood that no definitive findings will be } \\
\text { made regarding the capture of law enforcement } \\
\text { under the Zuma administration. Since } 2012 \\
\text { onwards, there were several court cases } \\
\text { that were pursued against individuals in law } \\
\text { enforcement, all of which have been either } \\
\text { dismissed or withdrawn. Most noteworthy are } \\
\text { the cases involved, amongst others: Anwa } \\
\text { Dramat and Shadrack Sibiya of the Hawks } \\
\text { (and Robert McBride from Independent Police } \\
\text { Investigative Directorate [IPID]) for allegations } \\
\text { related to the "Zimbabwean rendition" matter; } \\
\text { Johan Booysen for alleged racketeering as part } \\
\text { of "Cato Manor hit squad"; and the various } \\
\text { senior officials accused of being part of the } \\
\text { "rogue" intelligence unit at SARS. Other court } \\
\text { cases that have provided significant evidence } \\
\text { indicating the capture of law enforcement relate } \\
\text { to the irregular appointed allies of the Shadow } \\
\text { State capture network or the irrational removal } \\
\text { of potential opponents holding senior positions } \\
\text { in law enforcement. Example is the irregular } \\
\text { removal of Mxolisi Nxasana as National Director } \\
\text { of Public Prosecutions (NDPP). }\end{array}$ & $\begin{array}{l}\text { - Various } \\
\text { court cases, } \\
\text { proceedings } \\
\text { in Parlia- } \\
\text { ment } \\
\text { - Zondo } \\
\text { Commission }\end{array}$ & $\begin{array}{l}\text { - NPA } \\
\text { - SAPS } \\
\text { - Hawks } \\
\text { - IPID }\end{array}$ \\
\hline
\end{tabular}




\begin{tabular}{|c|c|c|c|c|}
\hline $\begin{array}{l}\text { Case Study } \\
\text { in State } \\
\text { Capture }\end{array}$ & Status & Summary Description & $\begin{array}{l}\text { Investigation } \\
\text { Body / } \\
\text { Source of } \\
\text { Evidence }\end{array}$ & $\begin{array}{l}\text { Government } \\
\text { Entity } \\
\text { Implicated }\end{array}$ \\
\hline \multicolumn{5}{|c|}{ Scandals Connected to Jacob Zuma, Guptas, Other Key Networks and ANC Politics } \\
\hline \multicolumn{5}{|c|}{ Investigations concerning Private Sector } \\
\hline $\begin{array}{l}\text { Budlender } \\
\text { report on } \\
\text { Trillian }\end{array}$ & $\begin{array}{l}\text { Released in } \\
\text { June } 2017 .\end{array}$ & $\begin{array}{l}\text { Trillian Holdings Board appointed Geoff } \\
\text { Budlender SC to undertake investigations into } \\
\text { State Capture allegations at Trillian Capital. } \\
\text { Detailed accounts from whistle-blowers } \\
\text { highlighted how information was withheld by } \\
\text { senior management at Trillian. }\end{array}$ & - Trillion & - Eskom \\
\hline $\begin{array}{l}\text { Collapse of } \\
\text { VBS Mutual } \\
\text { Bank }\end{array}$ & $\begin{array}{l}\text { Investigation } \\
\text { launched in } \\
\text { April } 2018 \text { and } \\
\text { the report was } \\
\text { released in } \\
\text { October } 2018 .\end{array}$ & $\begin{array}{l}\text { Minister of Finance placed VBS under } \\
\text { curatorship with effect from } 11 \text { March 2018. In } \\
\text { April 2018, the Deputy Governor of the South } \\
\text { African Reserve Bank instituted an investigation } \\
\text { into VBS. The outcomes of the investigation } \\
\text { showed blatant fraud and corruption by senior } \\
\text { executives/Board and how they extracted } \\
\text { money from the bank. Municipal funds were } \\
\text { illegally deposited with VBS (senior ANC and } \\
\text { EFF politicians have been implicated). }\end{array}$ & $\begin{array}{l}\text { - SARB } \\
\text { investiga- } \\
\text { tion report } \\
\text { VBS Mutual } \\
\text { Bank - The } \\
\text { Great Bank } \\
\text { Heist }\end{array}$ & $\begin{array}{l}\text { - Several } \\
\text { Provincial and } \\
\text { Municipal } \\
\text { Officials } \\
\text { (Limpopo } \\
\text { Government) } \\
\text { - SOEs } \\
\text { (particularly } \\
\text { PRASA) }\end{array}$ \\
\hline $\begin{array}{l}\text { SA Institute } \\
\text { of Chartered } \\
\text { Accountants' } \\
\text { (SAICA) } \\
\text { investigation } \\
\text { into KPMG }\end{array}$ & $\begin{array}{l}\text { Final report was } \\
\text { handed to SAICA in } \\
\text { December } 2018 .\end{array}$ & $\begin{array}{l}\text { SA Institute of Chartered Accountants (SAICA) } \\
\text { established an Inquiry to investigate state } \\
\text { capture related allegations of misconduct of its } \\
\text { members who worked for KPMG. The Inquiry } \\
\text { chaired by advocate Dumisa Ntsebeza held } \\
\text { public hearings and handed its final report to } \\
\text { SAICA in December 2018. Indications are that } \\
\text { the final report will not be made public until all } \\
\text { investigations and disciplinary hearings have } \\
\text { been finalised. }\end{array}$ & - SAICA & - Guptas \\
\hline Bell Pottinger & $\begin{array}{l}2017 \text { investigation } \\
\text { by PRCA. }\end{array}$ & $\begin{array}{l}\text { In 2016, the Guptas appointed British PR } \\
\text { company, Bell Pottinger, who developed and } \\
\text { promoted a campaign that underpinned the RET } \\
\text { and WMC narratives. In 2017, there was an } \\
\text { independent law firm review by Herbert Smith } \\
\text { Freehills resulting in Bell Pottinger's expulsion } \\
\text { from the Public Relations and Communications } \\
\text { Association (PRCA). }\end{array}$ & $\begin{array}{l}\text { - PRCA } \\
\text { - GuptaLeaks } \\
\text { - Ongoing } \\
\text { research } \\
\text { on disinfor- } \\
\text { mation }\end{array}$ & - Guptas \\
\hline
\end{tabular}

